\section{Nan Tien Institute}

231 Nolan St, Unanderra, NSW 2526, Australia.

Tel: $\quad$ (61) 242720648

Email:_info@nantien.edu.au

Website: www.nantien.edu.au

\section{Nan Tien Institute Postgraduate Scholarship}

Eligibility: Open to Australian domestic students only

Level of Study: Graduate, Postgraduate

Type: Scholarship

Value: AU $\$ 13,800.00$ covers tuition costs only (not text books, learning materials or accommodation) plus research supervision

Length of Study: Up to 3 years from commencement, unless otherwise agreed

Frequency: Annual

Study Establishment: Nan Tien Institute

Country of Study: Australia

Application Procedure: Complete and submit the application form, along with your application for admission form by the closing date

Closing Date: December

Contributor: Nan Tien Institute

Additional Information: Please check for more information at www.nantien.edu.au/content/nan-tien-institute-postgrad uate-scholarship scholarshipdb.net/jobs-in-Australia/Nan-TienInstitute-Postgraduate-Scholarship-Applied-Buddhist-StudiesResearch-Pathway-Pgabssrp-Nan-Tien-Institute $=\mathrm{Ox} 4 \mathrm{iZhJ75RG}$ UPAAlkGUTnw.html

\section{For further information contact:}

Tel: (61) 42580700

\section{Nansen Fund}

77 Saddlebrook Lane, Houston, TX 77024, United States of America.

Tel: $\quad$ (1) 7136863963

Contact: Fellowships Office

\section{John Dana Archbold Fellowship}

Purpose: To support educational exchange between the United States and Norway

Eligibility: Eligibility is limited to those aged between 20 and 35 , in good health, of good character, and citizens of the United States of America, who are not recent immigrants from Norway

Level of Study: Postdoctorate, Postgraduate, Professional development

Type: Fellowship

Value: Grants vary, depending on costs and rates of exchange. The University of Oslo will charge no tuition and the Nansen Fund will pay up to US $\$ 10,000$ for supplies, maintenance and travel. The maintenance stipend is sufficient to meet expenses in Norway for a single person. Air fare from the United States of America to Norway is covered

Length of Study: 1 year

Frequency: Every 2 years

Study Establishment: The University of Oslo

Country of Study: Norway

Application Procedure: Applicants must complete and submit an application form with references and transcripts

Closing Date: 31 January

Additional Information: Every other year the NorwayAmerica Association, the sister organisation of the Nansen Fund, offers fellowships for Norwegian citizens wishing to study at a university in the United States of America. For 
further information please contact The Norway-America Association

\section{For further information contact:}

The Norway-American Association, Drammensveien 20c, N-0271 Oslo, Norway.

Tel: $\quad$ (47) 22447716

Fax: (47) 22447716

Email: cg.newyork@mfa.no

\section{Nanyang Technological University (NTU)}

Nanyang Business School, Nanyang Avenue, 639798 Singapore.

Tel: $\quad$ (65) 67904803

Email: postgraduate@ntu.edu.sg

Website: www.ntu.edu.sg

Contact: Director

The Nanyang Business School is one of Asia's top business schools. Its flagship programme is the Nanyang MBA, which has consistently been ranked one of the top in Asia and is ranked in the world top 100 by Economist intelligence unit, 2005.

\section{Asia Journalism Fellowship}

Eligibility: At least five years of professional journalism experience, not including student journalism, who are currently working as a journalist. Freelancers are eligible, if journalism is their main activity. Applicants should be residing in Asia and should be able to operate in English which is the working language of the programme. Journalists working in non-English media are welcomed, but they will have to show their proficiency in English through a telephone interview. Permission is required from their employers to be away for the full three months of the Fellowship

Type: Fellowship

Value: Stipend of Singaporean $\$ \$ 1,500$ per month for the duration of the three month programme. Travel to and from Singapore will also be covered. There is no extra funding for spouses and children to visit. Free accommodation is provided in service apartments. Two or three Fellows share one apartment with kitchen to cook meals. Fellows will have access to the library, computer, internet and athletic facilities of the NTU campus. NTU will apply for Training Employment Passes for the Fellows to come to Singapore. Any visiting family members must handle their own entry permit applications

Country of Study: Singapore

Application Procedure: The mode of applying is electronically send to applications@ajf.sg

Closing Date: 25 October

Contributor: Temasek Foundation and Nanyang Technological University

Additional Information: The Fellowship brings around 15 journalists from across Asia to Singapore for three months www.ajf.sg/applying/

\section{For further information contact:}

Email: applications@ajf.sg

\section{Asian Communication Resource Centre (ACRC) Fellowship Award}

Purpose: To encourage in-depth research, promote cooperation and support scholars who wish to pursue research in communication, information and ICT-related disciplines in Asia

Eligibility: All applicants should possess or be working towards a postgraduate degree from a reputable academic institution and Applicants should be working on a research project in communication, media, information or related areas that would be able to exploit the materials in the ACRC

Level of Study: Postgraduate, Research

Type: Fellowships

Value: Up to US $\$ 1,500$ (economy class return air ticket), on-campus accommodation will be provided and weekly allowance of US $\$ 210$ will be provided

Length of Study: 1-3 months

Frequency: Annual

Application Procedure: Applicants can download the application form from the website and send in their completed application form along with a copy of their latest curriculum vitae

Closing Date: 1 October

Additional Information: liskw.wordpress.com/page/57/? arch_That

\section{For further information contact:}

Tel: $\quad$ (65) 67904577

Fax: (65) 67915214

Email: acrc_fellowship@ntu.edu.sg 


\section{Nanyang Technological University HASS International PhD Scholarship (HIPS) for Singaporean Students}

Purpose: HIPS aims to encourage outstanding Singapore citizens and Singapore permanent residents to pursue an academic career in HASS by supporting their doctoral studies abroad Eligibility: Under HIPS, the successful candidates will be employed as University staff. They will be granted paid leave to pursue a sponsored $\mathrm{PhD}$ programme in an approved overseas university or in NTU with an extended period of research in an approved overseas partner university. Upon successful completion of the $\mathrm{PhD}$ programme, they will be appointed as tenure-track Assistant Professors of the University

Type: Scholarship

Frequency: Annual

Application Procedure: Interested applicants should first get in touch with the relevant School and Division. Send all applications, through the respective Heads of Divisions/ Groups and School Chairs, to: Dean's Office (or to the Dean's office). Applicants who wish to submit their documents electronically should email their application form and complete dossier to Ms Chan Bee Kwang email: BKCHAN@ntu.edu.sg

Closing Date: 31 December

Additional Information: All late and/or incomplete applications will not be considered. A check list is included in the application package cohass.ntu.edu.sg/Programmes/Pages/ HIPS2020.aspx

\section{For further information contact:}

Email: wpseeto@ntu.edu.sg

\section{Singapore Education - Sampoerna Foundation MBA in Singapore}

Purpose: To help Indonesian citizens below 35 years pursue their MBA studies

Eligibility: Applicant must be an Indonesian citizen under 35 years, hold a local Bachelor's degree from any discipline with a minimum GPA of 3.00 (on a 4.00 scale), have a minimum of 2 year full-time professional work experience after the completion of the undergraduate degree, currently not enroled in graduate or post-graduate program, or obtained a Master's degree or equivalent; not be a graduate from overseas tertiary institutions, unless was on a full scholarship, not receive other equivalent award or scholarship offering similar or other benefits at the time of the award

Value: Approx. US\$70,000-150,000. This will cover GMAT and TOEFL/IELTS reimbursement, university application fee, student visa application fee, return airfares from Jakarta to the place of study, tuition fees for the duration of study, living allowance to support living costs during period of study and literature allowance to purchase textbooks required for study Country of Study: Any country

Closing Date: 1 February

Additional Information: For further information see www. nanyangmba.edu.sg/Admissions/FinancialAid.asp

\section{For further information contact:}

Email: ella.cecilla@sampoernafoundation.org

\section{Singapore International Graduate Award Awards for International Students in Singapore}

Purpose: Introducing a new Singapore International Graduate Award (or SINGA), for international students to do their $\mathrm{PhD}$ training in a multi-disciplinary environment in Singapore

Eligibility: International students with a passion for Science and Engineering research, excellent academic qualifications, good reports from academic referees, and fluency in English are encouraged to apply for this award. TOEFL, IELTS, and GRE are NOT required

Value: Stipends $-\mathrm{S} \$ 2,000$ per month ( $\$ \$ 24,000$ per annum), to be increased to $S \$ 2,500$ per month ( $\$ \$ 30,000$ per annum) after passing qualifying examinations; one-time $\mathrm{S} \$ 1,000$ settling-in allowance; one-time airfare grant of $\$ \$ 1,500$

Length of Study: 4 years

Country of Study: Singapore

Application Procedure: Applicants will need to complete and submit an online application form

Closing Date: 31 May

Additional Information: For more details, please visit the website wedushare.com/opportunity-detail/EXPT54EeMok7 Ew4EQ/SINGA-Awards-for-International-Students-in-Singa pore www.youthop.com/competitions/awards/singapore-inter national-graduate-award-singa-2019

For further information contact:

Email: singa_enquiries@hq.a-star.edu.sg

\section{Spring Management Development Scholarship (MDS)}

Purpose: To nurture the next generation of leaders for the trailblazing companies of tomorrow

Eligibility: Those who are currently working in an SME or are interested to join one, are citizens or permanent residents of Singapore, have less than 5 years of working experience and successfully apply for one of the approved MBA programmes 
Value: Full-time/Part-time MBA: SPRING will provide grant value of up to $70 \%$ of tuition fees, and other related expenses for full-time MBA scholars up to a maximum qualifying cost of $\mathrm{S} \$ 52,000$

Study Establishment: Nanyang Business School Country of Study: Singapore

Application Procedure: Applicants will have to go through a joint selection process by SPRING and the participating SME, serve a 3month internship in the SME prior to embarking on the approved MBA course (performance must be deemed satisfactory by the SME), and serve a bond of up to 2 years in the SME upon completion of studies. For more information on government assistance programmes, please contact the Enterprise One hotline at Tel: (65) 68981800 or email enterpriseone@spring.gov.sg or visit their website at www.spring.gov.sg/mds

Contributor: SPRING Singapore and small medium enterprises

Additional Information: For more information on government assistance programmes, please contact the Enterprise One hotline at Tel: (65) 68981800 or email enterpriseo ne@spring.gov.sg or visit their website at www.spring.gov. sg/mds scholarization.blogspot.com/2010/12/spring-manage ment-development.html

\section{For further information contact:}

Tel: (65) 68981800

Email: enquiry@enterprisesg.gov.sg

\section{The Lien Foundation Scholarship for Social Service Leaders}

Purpose: To provide scholarships to support education and professional development

Eligibility: The scholarship is open to candidates with academic excellence, notable performance record and the potential to take up leadership positions in voluntary welfare organizations

Type: Scholarship

Value: The award includes tuition fees, maintenance allowance (for full-time studies), book allowance and any other compulsory fees

Country of Study: Any country

Application Procedure: For more information on the scholarship do visit the websites www.ncss.org.sg/lien

Closing Date: 22 June

Additional Information: becas.universia.net/beca/lienfoundation-scholarship-for-social-service-leaders-/253628

\section{For further information contact:}

Email: socialservicescholarships@ncss.gov.sg

\section{Narotam Sekhsaria Foundation}

1st Floor, Nirmal Building, Nariman Point, Mumbai, Maharashtra 400021, India.

Tel: $\quad$ (91) 2261326200

Email: pgscholarship@nsfoundation.co.in

Contact: Narotam Sekhsaria Foundation

Narotam Sekhsaria Foundation is a non-profit initiative created to support enterprising individuals and innovative organizations.

\section{Narotam Sekhsaria Postgraduate Scholarship}

Purpose: The aim of the scholarship is to help high achieving students to pursue postgraduate studies at prestigious Indian and international universities

Eligibility: Applicants must have sufficient knowledge of the language of instruction of the host university

Type: Postgraduate scholarships

Value: The award of scholarship is subject to securing admission

Study Establishment: The scholarship is awarded in the fields offered by the university

Country of Study: India

Application Procedure: Applicants can apply through the registration process given below the link of scholarship page Closing Date: 28 March

Additional Information: For more details please see the website scholarship-positions.com/narotam-sekhsaria-postgrad uate-scholarship-indian-students/2017/11/07/ pg.nsfoundation. co.in/programmes.html

For further information contact:

Tel: (91) 2261326200

\section{National Academies}

500 5th Street NW, Washington, DC 20001, United States of America.

Tel: $\quad$ (1) 2023342000

Email: infofell@nas.edu

Website: www.nationalacademies.org

The National Academies perform an unparallelled public service by bringing together committees of experts in all 
areas of scientific and technological endeavour. These experts serve pro bono to address critical national issues and give advice to the federal government and the public.

\section{Christine Mirzayan Science \& Technology Policy Graduate Fellowship Program}

Purpose: To engage students in science and technology policy

Eligibility: Graduate students and postdoctoral scholars and those who have completed graduate studies or postdoctoral research within the last 5 years are eligible to apply

Level of Study: Postgraduate

Type: Fellowship

Value: The stipend for a 10 -week program is US\$5,300

Length of Study: 12 weeks

Frequency: Annual

Country of Study: Any country

Application Procedure: A completed application form must be submitted. Application forms are available on the website

Closing Date: September

Additional Information: mirzayanfellow.nas.edu/

\section{For further information contact:}

Email: policyfellows@nas.edu

\section{Ford Foundation Dissertation Fellowships}

Purpose: To achieve excellence in college and university teaching

Eligibility: Open to all citizens or nationals of the United States regardless of race, national origin, religion, gender, age, disability, or sexual orientation, individuals with evidence of superior academic achievement and committed to a career in teaching and research at the college or university level, $\mathrm{PhD}$ or $\mathrm{ScD}$ degree candidates studying in an eligible research-based discipline at a United States educational institution. Also individuals who have not earned a doctoral degree at any time, in any field

Level of Study: Doctorate

Type: Award

Value: Stipend: US\$25,000 for 1 year. Expenses paid to attend one Conference of Ford Fellows. Access to Ford Fellow Liaisons, a network of former Ford Fellows who have volunteered to provide mentoring and support to current fellows

Length of Study: 9-12 months

Frequency: Annual
Country of Study: United States of America

Application Procedure: Applicants must register and establish a personal user ID and password. Check website for further details

Closing Date: 15 November

Contributor: The National Research Council

Additional Information: www.petersons.com/scholarship/ ford-foundation-dissertation-fellowships-111_150501.aspx

\section{For further information contact:}

Tel: (1) 2023342872

\section{Ford Foundation Postdoctoral Fellowships}

Purpose: For achieving excellence in college and university teaching and to increase the diversity of the nation's college and university faculties by increasing their ethnic and racial diversity, to maximize the educational benefits of diversity, and to increase the number of professors who can and will use diversity as a resource for enriching the education of all students

Eligibility: Open to all citizens or nationals of the United States regardless of race, national origin, religion, gender, age, disability, or sexual orientation, individuals with evidence of superior academic achievement and committed to a career in teaching and research at the college or university level. Individuals should hold a $\mathrm{PhD}$ or $\mathrm{ScD}$ degree in an eligible research-based field from a United States educational institution

Level of Study: Postdoctorate

Type: Fellowships

Value: One-year Stipend: US\$45,000, Employing Institution Allowance: US\$1,500 and expenses paid to attend one Conference of Ford Fellows

Length of Study: 9-12 months

Application Procedure: Applicants must register and establish a personal user ID and password. Check website for further details

Closing Date: 15 November

Funding: Government, Foundation

Contributor: National Research Council (NRC) on behalf of the Ford Foundation

Additional Information: Candidates demonstrating superior academic achievement according to the judgement panels will be awarded pathwaystoscience.org/programhub.aspx? sort=PDC-NationalAcademies-PostDoc

\section{For further information contact:}

Tel: (1) 2023342872 


\section{Ford Foundation Predoctoral Fellowships}

Purpose: For achieving excellence in college and university teaching and increasing the diversity of the nation's college and university faculties to maximize the educational benefits of diversity, and to increase the number of professors who can use diversity as a resource for enriching the education of all students

Eligibility: Open to all citizens or nationals of the United States regardless of race, national origin, religion, gender, age, disability, or sexual orientation, individuals with evidence of superior academic achievement and committed to a career in teaching and research at the college or university level, should enrol in or planning to enrol in an eligible research-based program leading to $\mathrm{ahD}$ or $\mathrm{ScD}$ degree at a United States educational institution and who have not earned a doctoral degree at any time, in any field

Level of Study: Predoctorate

Type: Bursary and scholarship

Value: Annual stipend: US\$24,000. Award to the institution in lieu of tuition and fees: US\$2,000. Expenses paid to attend at least one Conference of Ford Fellows

Length of Study: 3 years

Application Procedure: Applicants must register and establish a personal user ID and password. Check website for further details

Closing Date: 19 November

Funding: Government, Foundation

Contributor: National Research Council on behalf of the Ford Foundation

Additional Information: Predoctoral fellows are required to enrol full-time in a program leading to a $\mathrm{PhD}$ or $\mathrm{ScD}$ degree in an eligible field of study www.petersons.com/scholarship/ ford-foundation-predoctoral-fellowships-111_150500.aspx

\section{For further information contact:}

Tel: (1) 2023342872

\section{Jefferson Science Fellowship}

Purpose: To offset the costs of temporary living quarters in the Washington, DC area

Eligibility: Applicants must be United States citizens and holding a tenured faculty position at a United States degree granting academic institution of higher learning. For terms and conditions as well as further details $\log$ on to the website Level of Study: Postgraduate

Value: The Jefferson Science Fellow will be paid a per diem of up to US\$50,000 by the United States Department of State and US $\$ 10,000$ will be made available to the Fellow for travel associated with their assignment(s)
Length of Study: 1 year

Frequency: Annual

Application Procedure: A complete nomination/application package consists of nomination/application form in PDF format and in word format; curriculum vitae (limit 10 pages); statements of qualifications (limit 2 pages each); and at least 3 , and no more than 5 , letters of recommendation from peers of the nominee/applicant

Closing Date: 14 January

Contributor: National Academies supported through a partnership between American philanthropic foundations, the United States STE academic community, professional scientific societies, and the United States Department of State Additional Information: Applicants should notify their institution while applying and encourage them to initiate a JSF/MOU as described on the website. Incomplete nomination/application packages, or those received after the deadline, will not be reviewed sites.nationalacademies.org/pga/jefferson/

\section{For further information contact:}

Tel: $\quad$ (1) 2023342643

Fax: (1) 2023342759

Email: jsf@nas.edu

\section{National Energy Technology Laboratory Methane Hydrates Fellowship Program (MHFP)}

Purpose: To provide postgraduate and postdoctoral candidates opportunities for career development, largely of their own choice in the Methane Hydrates field that are compatible with the interests of the sponsoring laboratories and universities, and to contribute thereby to the overall efforts of NETL in their support in the development of Methane Hydrate Science

Eligibility: Open to candidates holding appropriate prior degree for the level of fellowship they intend to pursue. An applicant's training, professional experience, and research experience may be in any appropriate discipline or combination of disciplines required for the proposed project. Each Methane Hydrate Program fellow will be closely affiliated with a Research Adviser at the host venue

Level of Study: Doctorate, Postdoctorate, Postgraduate

Type: Fellowship

Value: Stipend Rates: Master's Level (Fellow) begins at US $\$ 30,000$ with a maximum 2-year tenure, PhD Level (Fellow) begins at US $\$ 35,000$ with a maximum 3-year tenure and Postdoctoral Level (Research Associate) begins at US $\$ 60,000$ with a maximum 2-year tenure

Length of Study: 3 years

Application Procedure: Application must be submitted only in hard copy and sent by express delivery to the Associateship 
Programs office. After completing the WebRAP application, you must also mail your supporting documents (transcripts and references) to the same address

Closing Date: 15 August

Additional Information: Please check the website for further details. Please direct all Application inquiries directly to the Research Associateship Programs at rap@nas.edu or by phone at 2023342760

\section{For further information contact:}

Tel: $\quad$ (1) 2023342707

Email: ebasquest@nas.edu

\section{NRC Research Associate Programs (RAP)}

Purpose: The National Academies of Sciences, Engineering, and Medicine administers competitive postdoctoral and senior research awards on behalf of U.S. federal research agencies and affiliated institutions with facilities at over 100 locations throughout the U.S. and abroad.

Eligibility: See Individual Agency restrictions

Level of Study: Postdoctoral

Type: Fellowships

Value: NRC Research Associates receive annual stipends ranging from US\$45,000 to US\$80,000 for recent doctoral recipients and are proportionally higher for Senior Associates.

Length of Study: more than 5 years

Frequency: Annual

Closing Date: 5 January

Additional Information: sites.nationalacademies.org/PGA/ RAP/index.htm

\section{NRC Research Associateship Programs (RAP)}

Purpose: The goal of these programs is to provide advanced training and collaborative research opportunities for highly qualified graduate postdoctoral and visiting scientists

Eligibility: Prospective applicants should carefully read the details and eligibility of the program to which they are applying. Some laboratories have citizenship restrictions (open only to U.S. citizens and permanent residents)

Level of Study: Postdoctoral

Type: Fellowship

Length of Study: 5 years

Application Procedure: an application is submitted through the NRC Research Associateship Programs online application system

Closing Date: 1 November

Additional Information: sites.nationalacademies.org/PGA/ RAP/index.htm

\section{For further information contact:}

NRC Research Associateship Programs, 500 Fifth Street, NW, Washington, DC 20001, United States of America.

Tel: (1) 2023342760

Email: rap@nas.edu

\section{The Optical Society, Foundation Fellowships}

Purpose: The Optical Society of America Foundation inspires future optics innovators, supports career development for optics students, recent graduates, and young professionals and recognizes distinguished achievement in the field through the presentation of awards and honors. OSAF Fellowships are intended to provide career enhancing experiences to recent $\mathrm{PhDs}$ through postdoctoral research at an OSAF sponsoring company

Eligibility: Open to all nationalities; subject to visa requirements. Foreign nationals will be sponsored under a J-1 visa by the National Academy of Sciences.

Level of Study: Postgraduate

Type: Fellowship

Value: Stipend, health insurance allowance, relocation reimbursement, and funding for attendance and participation in OSA meetings and committees

Length of Study: One year with the possibility of renewal for additional year(s) based on adequate research progress and availability of funds

Additional Information: sites.nationalacademies.org/PGA/ osaff/index.htm

\section{For further information contact:}

The Optical Society, Foundation Fellowships, 500 Fifth Street NW, Keck 516, Washington, DC 2000, United States of America.

Tel: $\quad$ (1) 2023343478

Email: OSAFFellowships@nas.edu.

\section{National Aeronautics and Space Administration (NASA)}

NASA Headquarters, Suite 5R30, Washington, DC 20546, United States of America.

Tel: $\quad$ (1) 2023580001

Email: hfinquiry@stsci.edu

Website: www.nasa.gov

Contact: Public Communications Office 


\section{Hubble Fellowships for Postdoctoral Scientists}

Purpose: The Hubble Fellowship Program provides an opportunity for highly qualified recent postdoctoral scientists to conduct independent research that is broadly related to the NASA Cosmic Origins scientific goals as addressed by any of the missions in that program: the Hubble Space Telescope, Spitzer Space Telescope, Stratospheric Observatory for Infrared Astronomy (SOFIA), the Herschel Space Observatory, and the James Webb Space Telescope. The research will be carried out at United States Host Institutions chosen by each Fellow Eligibility: Applicants must have received a $\mathrm{PhD}$ or equivalent doctoral-level research degree in astronomy, physics, or a related discipline on or after 1 January (previous year). Graduate-student awardees who have not yet received their doctoral degree at the time of application must present evidence of having completed all requirements for the degree before commencing their Fellowships. Hubble Fellowships are open to citizens of the United States and to English-speaking citizens of other countries. Qualified applicants will receive consideration without regard to race, creed, color, age, gender, or national origin. Women and members of minority groups are strongly encouraged to apply. Incomplete applications and/or applications received after the deadline will not be considered Type: Fellowship

Value: An annual stipend of approx. US\$67,000 plus benefits, and an additional allowance of US\$16,000 per year for travel and other research costs. Funding will be provided initially for the first year of the Fellowship. Renewals for the second and third years will depend on annual performance reviews

Length of Study: Up to 3 years

Frequency: Annual

Country of Study: United States of America

Closing Date: 6 November

Additional Information: The Hubble Fellowship Program is administered for NASA by the Space Telescope Science Institute (STScI), operated by the Association of Universities for Research in Astronomy, Inc., working in cooperation with astronomical institutions throughout the United States. Awards will be made to support each Hubble Fellow through a designated Host Institution www.stsci.edu/stsci-research/ fellowships/nasa-hubble-fellowship-program

\section{National Air and Space Museum (NASM), Smithsonian Institution}

600 Independence Ave SW, Washington, DC 20560, United States of America.

Tel: $\quad$ (1) 2026332471

Email: colette.williams@nasm.si.edu

Website: www.nasm.si.edu
The Smithsonian Institution's National Air and Space Museum (NASM)maintains the largestcollection of historic air and spacecraftintheworld.Itisalsoavitalcentreforresearchintothehistory, scienceandtechnologyofaviationandspaceflight.

\section{A. Verville Fellowship}

Purpose: The Verville Fellowship is a competitive nine- to twelve-month in-residence fellowship intended for the analysis of major trends, developments, and accomplishments in the history of aviation or space studies

Level of Study: Research

Type: Fellowship

Value: An annual stipend of US $\$ 55,000$

Length of Study: 1 year

Study Establishment: NASM

Closing Date: 15 December

Funding: Private

\section{For further information contact:}

Email: NASM-Fellowships@si.edu.

\section{Charles A Lindbergh Chair in Aerospace History}

Purpose: To support senior scholars who are at work on, or anticipate being at work on, books on aerospace history

Eligibility: There are no eligibility restrictions

Level of Study: Research

Type: Fellowship

Value: US\$100,000

Length of Study: 1 year

Frequency: Annual

Study Establishment: Smithsonian Institution

Country of Study: United States of America

Application Procedure: Applicants must complete an application form

Closing Date: 15 January

Funding: Private

Contributor: Smithsonian restricted funds

Additional Information: airandspace.si.edu/support/getinvolved/fellowships/charles-lindbergh-chair-aerospace-history

\section{For further information contact:}

Email: collette.williams@nasm.si.edu

\section{Guggenheim Fellowship}

Purpose: Candidates are encouraged to pursue programs of research and writing that support publication of works that are scholarly 
Level of Study: Postdoctoral

Type: Fellowship

Value: An annual stipend of US $\$ 30,000$ for predoctoral candidates and US\$45,000 for postdoctoral candidates will be awarded, with limited additional funds for travel and miscellaneous

\section{Study Establishment: NASM}

Application Procedure: All applicants must be able to speak and write fluently in English

Closing Date: 15 December

Funding: Private

Additional Information: airandspace.si.edu/support/getinvolved/fellowships/guggenheim

\section{For further information contact:}

Email: NASM-Fellowships@si.edu.

\section{National Air and Space Museum Aviation/Space Writers Award}

Purpose: To support research on aerospace topics. The product created as a result of the grant must be in any form suitable for potential public dissemination in print, electronic, broadcast, or other visual medium, including, but not limited to, a book manuscript, video, film script, or monograph

Type: Award

Value: US $\$ 5,000$

Frequency: Annual

Application Procedure: 1. Maximum two-page, singlespaced proposal stating the subject of their research and their research goals 2. One- to two-page curriculum vitae 3. One-page detailed budget explaining how the grant will be spent.

Closing Date: March

Additional Information: airandspace.si.edu/support/getinvolved/fellowships/aviation-space-writers-foundation-award

\section{For further information contact:}

National Air and Space Museum, Independence Ave at Sixth Street, SW, Rm 3313, MRC 312, P.O. Box 37012, Washington, DC 20013-7012, United States of America.

Email: NASM-Fellowships@si.edu

\section{Postdoctoral Earth and Planetary Sciences Fellowship}

Purpose: To support scientific research

Level of Study: Postdoctorate

Type: Fellowship
Value: Stipend, compatible with National Research Council Awards

Length of Study: 1 or more years

Frequency: Dependent on funds available

Study Establishment: NASM

Country of Study: United States of America

Application Procedure: Applicants must complete an application form

Closing Date: 15 January

Funding: Private

Contributor: Smithsonian restricted funds

Additional Information: airandspace.si.edu/support/getinvolved/fellowships/postdoctoral-earth-and-planetary-sciences

\section{National Association for Core Curriculum, Inc.}

1640 Franklin Avenue, Suite 104, Kent, OH 44240-4324, United States of America.

\section{Tel: $\quad$ (1) 3306775008 \\ Email: gvarsnacc@aol.com \\ Contact: Dr Gordon F Vars, Executive Secretary \& Treasurer}

The National Association for Core Curriculum, Inc. has promoted integrative person centred education at all levels since 1953.

\section{Bossing-Edwards Research Scholarship Award}

Purpose: To encourage research on core curriculum and other interdisciplinary or integrative approaches to education

Eligibility: Open to individuals who have previously been a core teacher for at least one year, and have been accepted on a graduate programme leading to a Master's, specialist's or doctor's degree at a university that has adequate resources for research in core curriculum

Level of Study: Doctorate, Postgraduate

Type: Scholarship

Value: Up to US $\$ 300$

Frequency: Dependent on funds available

Study Establishment: An appropriate institution

Country of Study: United States of America

Application Procedure: Applicants should write explaining intended research and how they meet the criteria of eligibility

No. of awards offered: 5

Closing Date: 19 April

No. of awards given last year: 1

No. of applicants last year: 5 


\section{For further information contact:}

Email: canada@berkeley.edu

\section{National Association for Gifed Children}

\section{Davis Scholarship}

Purpose: Lewis \& Clark is pleased to announce its continuing commitment to the Davis United World College (UWC) Scholars program for the academic year

Level of Study: Postgraduate

Type: Scholarship

Value: US $\$ 20,000$

Length of Study: 4 year

Frequency: Annual

Country of Study: Any country

Closing Date: 15 February

Funding: Foundation

Additional Information: www.lclark.edu/offices/interna tional/financial_aid/davis_scholarship/

\section{For further information contact:}

Associate Dean of Students, Lewis \& Clark College, 0615 SW Palatine Hill Road, Portland, OR 97219, United States of America.

Tel: $\quad$ (1) 5037687305

Fax: (1) 5037687301

Email: iso@1clark.edu

\section{Distinguished Scholarship}

Purpose: The National Association for Gifted Children (NAGC) annually presents the Distinguished Scholar Award to an individual who has made significant contributions to the field of knowledge regarding the education of gifted and talented individuals. This individual should have a continued record of distinguished scholarship and contributions to the field of gifted education for more than 10 years, and must show a record of ongoing scholarly productivity as recognized by experts in the field

Eligibility: 1. Evidence of research in the field of gifted and talented. 2. Evidence that the contributions reflect a continuous and noted record of involvement in the field of gifted and talented education. 3. Evidence of recognition by peers of the importance of the above-mentioned contributions Level of Study: Postgraduate

Type: Scholarship

Value: US\$30,000
Length of Study: 4 year

Frequency: Annual

Country of Study: Any country

Closing Date: 1 February

Funding: Foundation

Additional Information: www.nagc.org/about/awardsrecognition/distinguished-scholar-award

\section{Goodrich Scholarship Program}

Purpose: Goodrich students establish a dynamic presence on campus. They come hungry, ready to learn and eager to join the UNO community. Many recipients are the first in their families to attend college. They come from underrepresented populations and have earned an opportunity to continue their education

Level of Study: Postgraduate

Type: Scholarship

Frequency: Annual

Country of Study: Any country

Funding: Foundation

\section{For further information contact:}

UNO Campus, 6001 Dodge Street, CPACS 123, Omaha Nebraska, NE 68182, United States of America.

Email: unogoodrich@unomaha.edu

\section{Paul Beck Memorial Scholarship}

Purpose: The Faculty Senate of the University of Nebraska Omaha (UNO) has sponsored scholarships for students since 1970 when Paul L. Beck, a long-time member of the History Department, urged faculty and staff to go beyond the classroom to assist capable students in their educational pursuits at UNO

Eligibility: 1. Applications must include a one page letter describing how this scholarship will help further your educational needs. 2. Applications must include a letter of support from a UNO faculty member. This letter must be sent directly to the Faculty Senate office by the faculty member. 3. No application will be considered unless all documents listed above are on file in the Faculty Senate office by the deadline. 4. Only one application/category per student is permitted

Level of Study: Postgraduate

Type: Scholarship

Value: US\$1,000

Frequency: Annual

Country of Study: Any country

Closing Date: 2 February 
Funding: Foundation

\section{For further information contact:}

The Faculty Senate, University of Nebraska at Omaha, ASH 105, 6001 Dodge St., Omaha Nebraska, NE 68182, United States of America.

Email: sbishop@unomaha.edu

\section{University of Nebraska Omaha Women's Club Scholarships}

Purpose: A portion of the UNOWC treasury funds are transferred each year to the scholarship fund, as are memorials. Our Annual Membership Fundraiser Dinner gives members a chance to contribute individually and to meet the scholarship winners. These and other projects, carried out over the years with a lot of work and dedication from many members, continue to increase the UNOWC Scholarship Funds

Level of Study: Postgraduate

Type: Scholarship

Value: US\$100

Frequency: Annual

Country of Study: Any country

Closing Date: 31 May

Funding: Foundation

Additional Information: www.unomaha.edu/womens-club/ scholarships.php

\section{For further information contact:}

Gina Pearson/Elaine Allen, University of Nebraska Foundation, 2285 S. 67th St., Ste 200, Omaha Nebraska, NE 68106, United States of America.

Email: uno.womens.club@gmail.com

\section{National Association of Teachers of Singing (NATS)}

9957 Moorings Drive, Suite 401, Jacksonville, FL 32257 , United States of America.

Tel: $\quad$ (1) 904992 9101; Toll Free: 8882622065

Email: info@nats.org

Website: www.nats.org

The National Association of Teachers of Singing (NATS) is now the largest association of teachers of singing in the world.
NATS offers a variety of lifelong learning experiences to its members, such as workshops, intern programmes, master classes, and conferences, all beginning at the chapter level and progressing to national events.

\section{National Association of Teachers of Singing Art Song Competition Award}

Purpose: To stimulate the creation of quality vocal literature through the cooperation of singer and composer

Eligibility: Open to any composer whose submitted work is a song cycle, group of songs, or extended single song of approximately 15 minutes in length (13-17 minutes acceptable); for single voice and piano; to a text written in English, for which the composer has secured copyright clearance (only text setting permission necessary); composed within the last 2 years, and who pays the competition entry fee

Type: Cash prize

Value: US $\$ 2,000$ plus the composer's expenses (US\$500 airfare reimbursement plus hotel) and US\$1,000, 2nd place

Study Establishment: Valdosta State University

Country of Study: United States of America

Application Procedure: check the website for further details Closing Date: 1 December

\section{For further information contact:}

DepartmentofMusic, ValdostaStateUniversity,1500N.Patterson Street, Valdosta,GA31602,UnitedStatesofAmerica.

Email: cmikkels@valdosta.edu

\section{National Breast Cancer Foundation (NBCF)}

Level 9, 50 Pitt St, Sydney 2000, GPO Box 4129, Sydney, NSW 2001, Australia.

Tel: $\quad$ (61) 280984800

Email: info@nbcf.org.au

Website: www.nbcf.org.au

The ultimate goal of the National Breast Cancer Foundation (NBCF) is to raise enough money to fund a cure for breast cancer. The NBCF supports and promotes research into breast cancer, facilitates consumer participation in all aspects of their work, acts as an advocate for breast cancer research, and provides opportunities for all Australians to contribute to breast cancer research. 


\section{National Breast Cancer Foundation Doctoral Scholarship}

Purpose: To provide outstanding graduates with a strong interest in breast cancer research with an opportunity to pursue full-time PhD studies at an Australian University

Eligibility: Open to applicants who are permanent residents of Australia

Level of Study: Doctorate, Postgraduate, Research

Type: Scholarship

Value: Scholars will receive a stipend of approx. AU $\$ 33,240$

Length of Study: 3 years

Frequency: Annual

Country of Study: Australia

Application Procedure: The applications are judged under peer review by experts in the field for their scientific merit and contribution to either new knowledge or building on existing knowledge of breast cancer

No. of awards offered: 15

Funding: Foundation

Contributor: Australian community and corporate funding

No. of awards given last year: 4

No. of applicants last year: 15

\section{For further information contact:}

Email:1han.gannon@nbcf.org.au

\section{Novel Concept Awards}

Purpose: To provide investigators with the opportunity to pursue serendipitous observations and explore new, innovative, and untested ideas

Eligibility: Open to applicants undertaking research in the entire continuum of breast cancer research. Residing in Australia throughout the funding period. Must meet all eligibility criteria outlined in guidelines and application form. Please check at www.nbcf.org.au

Level of Study: Unrestricted

Type: Research grant

Value: Maximum value of AU $\$ 100,000$ per grant per year

Length of Study: 1-2 years

Country of Study: Australia

Application Procedure: Please contact the Research Administrator or check the website for further details

No. of awards offered: 35

Closing Date: 20 June

Funding: Foundation, Trusts

Contributor: NBCF, Australian Community and Corporate No. of awards given last year: 12
No. of applicants last year: 35

Additional Information: Each year NBCF board will decide when to call for application and closing dates in late February

\section{Pilot Study Grants}

Purpose: To financially assist investigators to obtain preliminary data regarding methodology, effect sizes and possible findings relating to new research ideas relevant to breast cancer

Eligibility: Applicants must be Australian citizens, or be graduates from overseas with permanent Australian resident status, must reside in Australia throughout the funding period and not under bond to any foreign government

Level of Study: Research, Unrestricted

Type: Grant

Value: A maximum of AU $\$ 100,000$ for up to 2 years

Length of Study: Up to 2 years

Frequency: Every 2 years

Country of Study: Australia

Application Procedure: Check website for further details

No. of awards offered: 76

Closing Date: 10 May

Funding: Foundation

Contributor: Australian Community and Corporate

No. of awards given last year: 3

No. of applicants last year: 76

Additional Information: NBCF Board will decide whether to offer this grant scheme again when they meet annual in late February researchfunding.duke.edu/pilot-study-grants

\section{National Bureau of Asian Research (NBR)}

1414 NE 42nd Street, Suite 300, Seattle, WA 98105, United States of America.

Tel:

Email: nbr@nbr.org

Website: www.nbr.org

Contact: George F Russell

NBR is a nonprofit, nonpartisan research institution dedicated to informing and strengthening policy. NBR conducts advanced research on politics and security, economics and trade, and health and societal issues, with emphasis on those of interest to the United States. 


\section{The Next Generation: Leadership in Asian Affairs Fellowship}

Purpose: To further the professional development of Asian specialists in the year just after the completion of their Master's degree

Eligibility: Open to citizens or permanent residents of the United States who have obtained a Master's degree

Level of Study: Research

Type: Fellowships

Value: Each fellow will receive a US $\$ 32,500$ fellowship award (with benefits), as well as a reimbursement for some relocation expenses

Length of Study: 1 year

Frequency: Annual

Country of Study: United States of America

Application Procedure: Candidates must submit an online cover letter, curriculum vitae, 750 word essay stating the purpose of applying and 3 written references

Closing Date: 15 January

Funding: Government, Corporation, Foundation

No. of awards given last year: 3

Additional Information: www.honorsociety.org/scholar ships/next-generation-leadership-asian-affairs-fellowship

\section{For further information contact:}

Email: nextgen@nbr.org

\section{National Cattleman Foundation}

\section{Continuing Medical Education Beef Industry Scholarship}

Purpose: Sponsored by CME Group \& the National Cattlemen's Foundation, ten (10) scholarships of US\$1,500 will be awarded to outstanding students who are pursuing careers in the beef industry

Eligibility: Must be enrolled as an undergraduate student in a two or four-year institution of higher education for the entire upcoming academic year. Proof of enrollment as a full-time student will be required to receive the scholarship money; 1. Write a one-page letter expressing/indicating your future career goals related to the beef industry. 2. Write an essay of 750 words or less describing an issue confronting the beef industry and offer your solution. 3. Obtain two (2) letters of reference from current or former instructors or industry professionals. 4. Applications must contain the Beef Industry scholarship cover page
Level of Study: Graduate

Type: Scholarship

Length of Study: 2- 4 years

Frequency: Annual

Country of Study: United States of America and Europe

Closing Date: 30 October

Funding: Private

Additional Information: www.nationalcattlemens foundation.org/scholarships/cme-beef-industry-scholarship

\section{For further information contact:}

9110 East Nichols Ave., Suite \#300, Centennial, CO 80112, United States of America.

Email: ncf@beef.org

\section{National Education Association (NEA) Foundation}

1201 16th Street, North West, Washington, DC 20036, United States of America.

Tel: $\quad$ (1) 2028227840

Email: NEAFoundation@nea.org

Website: www.neafoundation.org

The NEA Foundation offers programs and grants that support public school educators' efforts to close the achievement gaps, increase student achievement, salute excellence in education and provide professional development.

\section{Student Achievement Grants}

Purpose: To promote collaborative, innovative ideas that lead to student achievement of high standards

Eligibility: Open to teams of two or more practising United States public school teachers in grades $\mathrm{K}-12$, public school education support personnel, public higher education faculty and staff. Preference will be given to National Education Association members, and to educators who serve economically disadvantaged and/or underserved students

Level of Study: Postgraduate

Type: Grant

Value: US\$2,000 and US $\$ 5,000$

Length of Study: 12 months

Frequency: Annual 
Country of Study: United States of America

Application Procedure: Applicants must consult the organization for details

Closing Date: 15 October

Additional Information: www.neafoundation.org/foreducators/student-success-grants/

\section{National Endowment for the Humanities (NEH)}

Division of Research, Room 318, 1100 Pennsylvania Avenue North West, Washington, DC 20506, United States of America.
Tel:
(1) 2026068400
Email:
research@neh.gov
Website:
www.neh.gov
Contact: Programme Officer

National Endowment for the Humanities' (NEH) Research Division facilitates research and original scholarship in the humanities through grants to universities, centres for advanced study and individual scholars. NEH uses the following definition of the humanities: 'The humanities include, but are not limited to, language, both modern and classical, linguistics, literature, history, jurisprudence, philosophy, archaeology, comparative religion, ethics, the history, criticism and theory of the arts, aspects of social sciences which have humanistic content and employ humanistic methods, and the study and application of the humanities to the human environment with particular attention to reflecting our diverse heritage, traditions and history and to the relevance of the humanities to the current conditions of national life'.

\section{National Endowment for the Humanities Fellowships}

Purpose: To provide support for full-time research on projects that can be completed during the tenure of the award, as well as for work that is part of a long-term endeavour. Recipients usually produce scholarly articles, monographs on specialised subjects, books on broad topics, archaeological site reports, translations, editions or other scholarly tools

Eligibility: Open to faculty or staff members of colleges or universities, or of primary or secondary schools, or independent scholars or writers

Level of Study: Postdoctorate

Type: Fellowship

Value: US\$24,000 for six-eight month tenure and US\$40,000 for 9-12 month tenure
Length of Study: Varies

Frequency: Annual Country of Study: Other

Application Procedure: Applicants must complete and submit an application form. Guidelines and application forms are posted on the NEH website

Closing Date: 1 May

Funding: Government

For further information contact:

Email: questions@neh.gov

\section{National Foundation for Infectious Diseases (NFID)}

7201 Wisconsin Avenue, Suite 750, Bethesda, MD 20814, United States of America.

Tel: $\quad$ (1) 3016560003

Email: info@nfid.org

Website: www.nfid.org

The National Foundation for Infectious Diseases (NFID) is a non-profit, non-governmental organization whose mission is public and professional education and promotion of research on the causes, treatment and prevention of infectious diseases.

\section{National Foundation for Infectious Diseases Postdoctoral Fellowship in Nosocomial Infection Research and Training}

Purpose: To encourage a qualified physician researcher to become a specialist and investigator in the field of nosocomial infections

Eligibility: Open to citizens of the United States

Level of Study: Postgraduate

Type: Fellowship

Value: US\$40,000

Frequency: Annual

Country of Study: United States of America

Application Procedure: Applicants must submit their application form and curriculum vitae

Closing Date: 6 January

Additional Information: Contact Grants Manager. Priority will be given to Fellows in or entering into infectious diseases training www.neh.gov/grants/research/fellowships

\section{For further information contact:}

Email: nfid@aol.com 


\section{National Health and Medical Research Council (NHMRC)}

NHMRC, GPO Box 1421, Canberra, ACT 2601, Australia.

Tel: $\quad$ (61) 262179000

Email: grantnet.help@nhmrc.gov.au

Website: www.nhmrc.gov.au

Contact: Executive Director

The National Health and Medical Research Council (NHMRC) (Australia) consolidates within a single national organization the often independent functions of research funding and development of advice. One of its strengths is that it brings together and draws upon the resources of all components of the health system, including governments, medical practitioners, nurses and allied health professionals, researchers, teaching and research institutions, public and private programme managers, service administrators, community health organizations, social health researchers and consumers.

\section{National Health and Medical Research Council Equipment Grants}

Purpose: To provide funding support for the purchase of items of equipment required for biomedical research

Eligibility: Open to individuals, groups or institutions which are normally eligible for NHMRC support. Grants will be made on the basis of scientific merit, taking into consideration factors including whether the applicants hold NHMRC grants, the institutional ranking of the application, and institutional or regional availability of major equipment

Level of Study: Unrestricted

Type: Grant

Value: AU $\$ 10,000$ to cover the cost of equipment in excess of

Frequency: Annual

Country of Study: Australia

Application Procedure: Applicants must complete an application form

Funding: Government

\section{For further information contact:}

MDP 33, Project Grants Office, GPO Box 9848, Canberra, ACT 2601, Australia.

Tel: $\quad$ (61) 262898278

Fax: (61) 262898617

Email: jean.sewell@hhlgcs.ausgovhhcs.telememo.au

\section{National Health and Medical Research Council Public Health Travelling Fellowships}

Purpose: To enable Fellows to make postgraduate study tours abroad or within Australia, which relate to their work and speciality and which will be of benefit to public health in Australia

Eligibility: Open to all personnel working in the field of public health, who are suitably qualified at a level appropriate for fulfilment of the objectives of the study and for implementation of its benefits. The applicant may be employed in government or industry, or may be self-employed. Preference will be given to those applicants who would not normally, in the course of their employment, have the opportunity, as part of their normal duties, for overseas travel and experience

Level of Study: Unrestricted

Type: Other

Value: Not exceeding AU\$19,700, plus an agreed annual allowance to cover cost increases

Length of Study: 2-12 months

Frequency: Annual

Country of Study: Any country

Application Procedure: Please write for details

No. of awards offered: 18

Closing Date: 31 July

Funding: Government

No. of awards given last year: 8

No. of applicants last year: 18

Additional Information: Preference will be given to public health practitioners

\section{For further information contact:}

Secretariat \& Training Awards, GPO Box 9848, Canberra, ACT 2601, Australia.

Tel: $\quad$ (61) 262897945

Fax: (61) 262896957

Email: trevorlord@hhlgcs.ausgovhhcs.telememo.au

\section{National Health and Medical Research Council Research Project Grants}

Purpose: To provide support for work on problems which are likely to be capable of solution in a reasonably short period of time

Eligibility: Open to Australian researchers only

Level of Study: Unrestricted

Type: Grant

Value: To cover salary, equipment, maintenance and other specific expenses

Frequency: Annual

Country of Study: Australia 
Application Procedure: Applicants must complete an application form

No. of awards offered: 1299

Closing Date: 6 March

Funding: Government

No. of awards given last year: 406

No. of applicants last year: 1299

For further information contact:

Project Grants Office, GPO Box 9848, Canberra, ACT 2601, Australia.

Tel: $\quad$ (61) 262896974

Fax: (61) 262898617

Email: elizabeth.hoole@hhlgcs.ausgovhhcs.telememo.au

\section{R Douglas Wright Awards}

Purpose: To provide outstanding researchers at an early stage in their career with an opportunity for independent research together with improved security

Eligibility: Open to applicants who have completed postdoctoral research training or have equivalent experience, and are seeking to establish themselves in a career in medical research in Australia

Level of Study: Postdoctorate, Professional development

Type: Award

Value: Salary in the range of Senior Research Officer Level

1 to Senior Research Officer Level 4, with annual increments, plus an allowance of AU\$10,000 per year

Length of Study: 4 years

Frequency: Annual

Study Establishment: Australian research institutions

Country of Study: Australia

Application Procedure: Applicants must complete an application form, available from Ms H Murray

No. of awards offered: 43

Closing Date: 30 April

Funding: Government

No. of awards given last year: 6

No. of applicants last year: 43

Additional Information: staff.unimelb.edu.au/mdhs/ research-development/research-collaboration-and-funding/ faculty-trust-fellowships/r-douglas-wright-research-fellowship

\section{For further information contact:}

Fellowships Unit - Mail Drop Point, 33GPO Box 9848, Canberra, ACT 2601, Australia.

Tel: $\quad$ (61) 262895034

Fax: (61) 262891329

Email: helen.murray@hhlgcs.ausgovhhcs.telememo.au

\section{Targeted Call for Research into Healthy Ageing of} Aboriginal and Torres Strait Islander Peoples

Purpose: The aim of implementing this call is to provide funding for rigorous, culturally-informed research into improving the health and experiences of ageing in older Aboriginal and Torres Strait Islander peoples. Quality evidence generated from research will allow for better planning, funding and implementation of policies and services to achieve and support healthy ageing for Aboriginal and Torres Strait Islander peoples

Eligibility: Applications for NHMRC funding are subject to the general eligibility requirements set out in the NHMRC Funding Rules. Additional eligibility requirements are in scheme-specific funding rules. Institutions must be an NHMRC approved Administering Institution to be eligible to receive and administer NHMRC funding - refer to the NHMRC website for a list of approved Administering Institutions

Level of Study: Graduate

Type: Grant

Value: Total value available is AU\$5,000,000

Frequency: Annual

Country of Study: Any country

Application Procedure: Official website to apply electronically for the grant application is www.nhmrc.gov.au/grantsfunding-administering-grants

Closing Date: 15 August

Funding: Private

Additional Information: Applications must be submitted electronically using NHMRC's online Research Grants Management System (RGMS). Official link for the following grant is www.nhmrc.gov.au/grants-funding-administeringgrants www.nhmrc.gov.au/funding/find-funding/targeted-callresearch-healthy-ageing-aboriginal-and-torres-strait-islanderpeoples

For further information contact:

Email: help@nhmrc.gov.au

\section{National Heart, Lung, and Blood Institute}

\section{Immersive Training in the Glycosciences - Fellowship}

Subjects: Glycosciences

Purpose: The ultimate goal of the program is to transform the study of glycoscience from a specialized domain into mainstream biology. This fellowship is expected to provide scholars with an unparalleled opportunity to participate in 
cross-disciplinary research, obtain advanced knowledge, skills, and professional exposure within the glycosciences, as well as to develop a research portfolio from which to launch independent careers.

Eligibility: Scholars must be citizens or non-citizen nationals of the United States or have been lawfully admitted for permanent residence at the time of appointment. At the time of appointment scholars should hold an M.D. and/or PhD degree.

Type: Fellowship

Value: Salary support of up to US\$100,000 per year (inclusive of benefits), research supplies, and travel. Rigorous training in the Glycosciences (didactic and technical) will be provided.

Study Establishment: John Hopkins University

Country of Study: United States of America

Closing Date: 30 July

Additional Information: glycocareers.cclinic.jhu.edu/ styled/index.html

\section{National Institute for Health and Care Excellence (NICE)}

Level 1A, City Tower, Piccadilly Plaza, Manchester, M1 4BT, United Kingdom.

Tel: $\quad$ (44) 3003230140

Website: www.nice.org.uk

The National Institute for Health and Care Excellence (NICE) provides national guidance and advice to improve health and social care. NICE was originally set up in 1999 as the National Institute for Clinical Excellence, a special health authority, to reduce variation in the availability and quality of NHS treatments and care.

\section{National Institute for Health and Care Excellence Scholarships}

Purpose: NICE Scholarships are one-year opportunities for qualified health and social care professionals to find out about the inner workings of NICE and undertake a supported improvement project, related to NICE guidance, within their local organization

Eligibility: NICE Scholarships are typically awarded to specialist registrars, senior nurses, pharmacists and allied health professionals, service improvement leads, public health and social care specialists and health service managers. In addition to their project-based activities, NICE Scholars are expected to act as local ambassadors for clinical and public health and social care excellence; promote the principles and the recommendations of NICE guidance-through teaching activities, for example

Type: Scholarship

Value: NICE Scholars are supported in their project via a series of workshops, access to a very experienced senior mentor and contact with the expert teams at NICE. NICE Scholars are not paid. NICE will, however, meet all reasonable expenses (e.g. travel, accommodation) incurred in the course of carrying out Scholarship activities

Length of Study: 1 year

Frequency: Annual

Country of Study: United Kingdom

Application Procedure: The mode of applying is by post

Closing Date: 1 November

Additional Information: Scholars are expected to devote approximately 7.5 hours per week to their Scholarship project. For detailed information, visit www.nice.org.uk/ getinvolved/nice_fellows_and_scholars/scholars/NICEScho larships.jsp scientistsolutions.com/forum/jobs-clinicaldiagno stic/national-institute-health-and-care-excellence-scholarships

\section{National Institute of General Medical Sciences (NIGMS)}

45 Center Drive, MSC 6200, Bethesda, MD 20892-6200, United States of America.

Tel: (1) 3014967301

Email: info@nigms.nih.gov

Website: www.nigms.nih.gov

Contact: Ms Jilliene Drayton, Information Development Specialist

The National Institute of General Medical Sciences (NIGMS) is one of the National Institutes of Health (NIH), the principal biomedical research agency of the United States Federal Government. NIGMS supports basic research that increases understanding of biological processes and lays the foundation for advances in disease diagnosis, treatment, and prevention.

\section{National Institute of General Medical Sciences Research Project Grants (R01)}

Purpose: To support a discrete project related to the investigator's area of interest and competence

Eligibility: Research project grants may be awarded to nonprofit organizations and institutions; governments and their agencies; occasionally, though rarely, to individuals who have access to adequate facilities and resources for conducting the 
research; and to profit-making organizations. Foreign institutions and international organizations are also eligible to apply for these grants

Level of Study: Postgraduate

Type: Grant

Value: These grants may provide funds for reasonable costs of the research activity, as well as for salaries, equipment, supplies, travel and other related expenses

Frequency: Annual

Country of Study: United States of America

Application Procedure: Applicants must contact the Office of Extramural Outreach for details

Funding: Government

Additional Information: www.grants.nih.gov/supportwww. nigms.nih.gov/Research/Mechanisms/Pages/ResearchProject Grants.aspx

\section{For further information contact:}

Office of Extramural Outreach, NIH 6701 Rockledge Drive Msc 7760, Bethesda, MD 20892-7760, United States of America.

Tel: $\quad$ (1) 3014350714

Email: grantsinfo@nih.gov

\section{National Road Safety Authority Individual Postdoctoral Fellowships (F32)}

Purpose: NIGMS welcomes NRSA applications from eligible individuals who seek postdoctoral biomedical research training in areas related to the scientific programmes of the Institute

Eligibility: Open to applicants who have received the doctoral degree (domestic or foreign) by the beginning date of the proposed award

Level of Study: Postdoctorate

Type: Award

Value: NIGMS provides an annual stipend to postdoctoral fellows, and an institutional allowance to cover trainingrelated expenses. The stipend, tuition/fees and institutional allowance are detailed at

Length of Study: Up to 3 years

Frequency: Annual

Study Establishment: The institutional setting may be domestic or foreign, public or private

Country of Study: Any country

Application Procedure: Applicants must write to the main address for details or telephone Dr Michael Sesma, at (1) 301 5942772 . Further details are also available from the website www.nigms.nih.gov

Closing Date: 8 April
Funding: Government

Additional Information: www.nigms.nih.gov/training/ indivpostdoc/Pages/PostdocFellowshipDescription.aspx

\section{National Institutes of Health}

900 Rockville Pike, Bethesda, MA 20892, United States of America.

\author{
Website: www.nih.gov \\ Contact: Dr Belinda Seto, Acting Deputy Director for \\ Extramural Research
}

\section{Hitchings-Elion Postdoctoral Fellowships for United States Scientist}

Purpose: The purpose of these fellowships is to promote scientific collaboration between British and American scientists for the conduct of biomedical and behavioral research Eligibility: The applicant must be a United States citizen or permanent United States resident, hold a doctorate level degree in one of the medical or veterinary clinical, behavioral, or biomedical sciences, and be within ten years of the last doctoral degree

Level of Study: Research

Type: Fellowship

Frequency: Annual

Country of Study: Any country

Application Procedure: The administration of the program will be integrated into the administration of other Fogarty International Center fellowship activities and the application receipt processes of the Division of Research Grants, NIH. Applications must be sent to the Division of Research Grants, NIH. Special application forms must be used and are available, along with detailed instructions from International Research and Awards Branch. Fogarty International Center National Institutes of Health Building 31, Room $\mathrm{B} 2 \mathrm{C} 39$

Closing Date: 10 September

Funding: Private

Additional Information: grants.nih.gov/grants/guide/pafiles/PA-92-030.html

\section{For further information contact:}

Chief, International Research and Awards Branch, Fogarty International Center, Building 31, Room B2C21, Bethesda, MD 20892, United States.

Tel: (1) 3014961653 


\section{Ruth L. Kirschstein National Research Service Award (NRSA) Individual Postdoctoral Fellowship}

Purpose: To support promising applicants during their mentored postdoctoral training under the guidance of outstanding faculty sponsors

Level of Study: Postdoctoral

Type: Fellowships

Value: stipend, allowance \& tuition

Frequency: Annual

Closing Date: 8 April

Additional Information: grants.nih.gov/grants/guide/pafiles/PA-19-188.html

\section{National Library of Medicine (NLM)}

8600 Rockville Pike Building 38A, Bethesda, MD 20894, United States of America.

\section{Tel: $\quad$ (1) 3014964221 \\ Email:_dm99n@nih.gov \\ Website: www.nlm.nih.gov \\ Contact: Mr Dwight Mawrery, Grants Management Officer}

As one of the nation's premier repositories of biomedical information, the National Library of Medicine (NLM) has a vital interest in information management and in the enormous utility of computers and telecommunications for improving storage, retrieval, access and use of biomedical information. The Library offers support for qualified investigators, be they individuals or institutions, in three separate but related programme areas: medical informatics, biotechnology information and health sciences library and information science.

\section{National Library of Medicine Fellowship in Applied Informatics}

Purpose: To improve the American healthcare system by supporting health science professionals (including librarians) whose primary interest is to put informatics into practice, develop modern information systems in traditional organisations, use the new information techniques in a specific field and help disseminate promising programmes and systems Eligibility: Open to individuals with a BA, BSc, MA, MSc or $\mathrm{PhD}$ in a field related to health, who are United States nationals or permanent residents of the United States of America
Level of Study: Doctorate, Graduate, Postdoctorate, Postgraduate

Type: Fellowship

Value: Up to US $\$ 58,000$ per year, based on the salary or remuneration the individual would have been paid from their home institution

Length of Study: Varies

Frequency: Annual

Study Establishment: Universities, colleges, hospitals, laboratories, units of State and certain agencies of the Federal Government in the United States

Country of Study: United States of America

Application Procedure: Applications must be submitted by an organisation on behalf of the individual seeking the grant, on the standard grant application form PHS 416-1 (rev 8/95)

Closing Date: 5 December

Additional Information: The NLM encourages potential applicants to clarify any issues or questions. For enquiries regarding programmatic issues, please contact $\mathrm{Mr}$ Peter Clepper, Program Officer. For enquiries regarding Division of Nursing programmatic issues, please contact the Division of Nursing. For enquiries regarding fiscal matters, please contact Ms Shelley Carow, Grants Management Officer grants.nih.gov/grants/guide/pa-files/PA-92-090.html

\section{For further information contact:}

Division of Nursing, Parklawn Building, Room 9-36, 5600 Fishes Lane, Rockville, MD 20852, United States of America.
Tel: $\quad$ (1) 3014435786
Fax: (1) 3014438586

\section{National Library of Medicine Investigator Initiated Project Grant}

Purpose: To support individual investigators and their colleagues to pursue a discreet, circumscribed line of investigation to its logical conclusion

Type: Project grant

Length of Study: Up to 3 years

Frequency: 3 times each year

Study Establishment: United States universities or research institutions

Country of Study: United States of America

Application Procedure: Applications must be submitted on the PHS form 398 (ref 5/95)

Closing Date: 1 October

Additional Information: grants.nih.gov/grants/guide/pafiles/PA-96-001.html 


\section{For further information contact:}

Division of Extramural Programmes, National Library of Medicine, Rockledge One Building, 6705 Rockledge Drive Suite 301, Bethesda, MD 20817, United States of America.
Tel:
(1) 3015944882
Fax:
(1) 3014022952
Email: bean@nlm.nih.gov

\section{National Library of Medicine Postdoctoral Informatics Research Fellowships}

Purpose: To promote researchers interested in informatics research training wishing to identify their own mentor and host institution

Eligibility: Open to applicants who have a $\mathrm{PhD}$ relevant to biomedicine or computer science or an equivalent degree from an accredited domestic or foreign institution

Level of Study: Postdoctorate

Type: Fellowship

Value: Based on established NIH schedules

Frequency: Annual

Study Establishment: United States universities or research institutions

Country of Study: United States of America

Application Procedure: Applicants must contact the organisation

Additional Information: For a complete list of NLM factsheets, please contact Factsheets, Office of Public Information

\section{For further information contact:}

Factsheets Office of Public Information National Library of Medicine, 8600 Rockville Pike, Bethesda, MD 20894, United States of America.

Fax: (1) 3014964450

Email: publicinfo@nlm.nih.gov

\section{National Library of Medicine Publication Grant Program}

Purpose: To provide assistance for the preparation of book length manuscripts and, in some cases, the publication of important scientific information needed by United States health professionals

Eligibility: Open to public or private, non-profit institutions and individuals, who are involved in research
Type: Project grant

Value: US $\$ 35,000$ direct costs per year over a period of three years maximum

Length of Study: $1-3$ years

Frequency: 3 times each year

Country of Study: United States of America

Application Procedure: Applications must be submitted on the PHS FORM 398 (Rev 5/95) grant application kit

Closing Date: 1 October

Additional Information: Potential applicants are strongly encouraged to discuss projects early with the Program staff, who will discuss programme status and experience with them, provide additional information in response to specific application plans and review draft proposals for completeness if desired. For a complete list of NLM Factsheets, please contact Factsheets, Office of Public Information

\section{For further information contact:}

Tel: $\quad$ (1) 3015944882

Fax: (1) 3014022952

Email: sparks@nlm.nih.gov

\section{National Multiple Sclerosis Society} (MS)

National MS Society, P.O. Box 4527, New York, NY 10163, United States of America.

Tel: $\quad$ (1) 8003444867

Website: www.nationalmssociety.org/

The National Multiple Sclerosis Society (NMSS) is a non-profit organization based in New York City with chapters located throughout the United States. The organization funds research, advocates for social and political change, provides education, and sponsors services that help people with multiple sclerosis and their families.

\section{Career Transition Fellowships}

Purpose: The Society's Career Transition Fellowship addresses this need by fostering the development and productivity of young scientists who have potential to make significant contributions to MS research and help ensure the future and stability of MS research. The Career Transition Fellowship targets current postdoctoral trainees who demonstrate 
both commitment and exceptional potential to conduct MS-related research.

Eligibility: Applicants must hold a doctoral degree (M.D., $\mathrm{PhD}$ or equivalent) and must be in a research-oriented postdoctoral training program. Individuals with less than two or more than five years of postdoctoral research experience at the time of application are ineligible for this award.

Type: Fellowships

Value: US\$550,000

Length of Study: 5 years

Frequency: Annual

Application Procedure: The application process for this award involves two levels of review, preliminary and full applications. To submit a proposal for research support, investigators must first register with our Apply Online site (nmss. fluxx.io) and complete a pre-application. Staff will review the pre-applications and selected applicants will be invited to submit a full proposal.

Closing Date: 21 August

Additional Information: www.nationalmssociety.org/ForProfessionals/Researchers/Society-Funding/Training-Grantsand-Fellowships/Career-Transition-Fellowships

\section{For further information contact:}

Email: Douglas.Landsman@nmss.org

\section{National Research Council (NRC)}

500 Fifth Street NW, Washington, DC 20001, United States of America.

Tel: (1) 2023342644

The National Research Council (NRC) was organized by the National Academy of Sciences in 1916 to associate the broad community of science and technology with the Academy's purposes of further knowledge and advising the federal government.

\section{Christine Mirzayan Science \& Technology Policy Graduate Fellowship Program}

Country of Study: Any country

Additional Information: mirzayanfellow.nas.edu/

\section{For further information contact:}

Email: policyfellows@nas.edu

\section{National Research Foundation (NRF)}

PO Box 2600, Pretoria 0001, South Africa.

Tel: $\quad$ (27) 124814209

Email: haveline@nrf.ac.za

Website: www.nrf.ac.za

Contact: Ms HA Michau, Manager, Student Support

The National Research Foundation (NRF) is responsible for funding South African research and other expertise in the fields of the social, natural and applied sciences, humanities, engineering and technology. The NRF is funded by the government, but also pursues joint ventures and collaboration with industry and the international community to increase the impact of its activities.

\section{Innovation Masters and Doctoral Scholarships}

Eligibility: Scholarships are open to South African citizens, South African permanent residents as well as a limited percentage of non-South African citizens registered at a South African public university

Level of Study: Postgraduate

Value: Masters scholarships worth ZAR 80,000 per annum and doctoral scholarships worth ZAR 110,000 per annum Country of Study: South Africa

Application Procedure: Please check website for more details

Closing Date: 7 August

Contributor: Funded by Department of Science and Technology (DST) and managed by the National Research Foundation (NRF)

Additional Information: www.nrf.ac.za/document/ innovation-masters-and-doctoral-scholarships-call-2015

\section{For further information contact:}

Email: futurestudents@bournemouth.ac.uk

\section{National Research Foundation Fellowships for Postdoctoral Research}

Purpose: To foster postdoctoral research in the natural and applied sciences, engineering, social sciences and the humanities

Eligibility: Open to any nationals who have received their PhD within the last 5 years

Level of Study: Postdoctorate 
Type: Fellowship

Value: Up to ZAR 60,000 plus a contribution of ZAR 10,000 towards the running cost of the project

Length of Study: Up to 2 years

Frequency: Twice a year

Study Establishment: Any university, technikon or research institute for full-time research

Country of Study: South Africa

Application Procedure: Applicants must complete and submit an application form, full academic record and the names of referees. Forms are available from the bursary offices of universities and technikons or can be downloaded from the website

No. of awards offered: 150

Closing Date: 31 July

Funding: Government

No. of awards given last year: 50

No. of applicants last year: 150

For further information contact:

Email: fellowships@twas.org

\section{National Research Foundation Free-standing Masters and Doctoral Scholarships}

Eligibility: Scholarships are open to South African citizens, South African permanent residents as well as a limited percentage of non-South African citizens registered at a South African public university. All applicants for full-time Masters or Doctoral studies in South Africa must be registered or intending to register at a South African public university. Applicants that already hold a degree at the level for which they are applying for funding are not eligible

Level of Study: Doctorate

Value: Masters scholarships worth ZAR 50,000 per year and doctoral scholarships worth ZAR 70,000 per year

Frequency: Annual

Country of Study: South Africa

Application Procedure: Applications must be submitted through an online application process to the NRF

Closing Date: 7 August

Funding: International office

Additional Information: www.opportunitiesforafricans. com/nrf-masters-and-doctoral-scholarships-2018-2019-foryoung-south-africans/

For further information contact:

Email: CGSMSFSS-SEEMSBESC@cihr-irsc.gc.ca
National Research Foundation Targeted Research Awards Competitive Industry Programme

Purpose: To support research in priority areas where expertise is lacking

Eligibility: Open to South African citizens only, who qualify for postgraduate support. Postdoctoral support is available for any nationality

Level of Study: Doctorate, Postdoctorate, Postgraduate

Type: Research grant

Value: From a total of approximately rand 20 million per year

Frequency: Annual

Study Establishment: Any tertiary educational institution in South Africa

Country of Study: Other

Application Procedure: Applicants must complete an electronic application form. For further information please contact Ms Jill Sawers

No. of awards offered: 200

Closing Date: 31 July

Funding: Government

No. of awards given last year: 181

No. of applicants last year: 200

Additional Information: Joint ventures and collaboration with industry are strongly encouraged

For further information contact:

Tel: (27) 124814104

Email: jill@frd.ac.za

\section{National Research Foundation Visiting Fellowships}

Purpose: To strengthen areas of expertise needed in South Africa

Eligibility: Open to senior scientists of any nationality

Level of Study: Postdoctorate

Type: Fellowship

Value: To cover air fares and accommodation

Length of Study: Up to 3 months

Frequency: Annual, if funds are available

Study Establishment: Any South African university, technikon, museum or scientific society

Country of Study: South Africa

Application Procedure: Applications should be submitted by a South African counterpart attached to a South African university, technikon, museum or scientific society 


\section{For further information contact:}

Meiring Naude Rd, Gauteng, Pretoria 0184, South Africa.

Tel: (27) 124814122

Email: ferdi@frd.ac.za

\section{Vrije University Amsterdam-NRF Desmond Tutu Doctoral Scholarships}

Eligibility: Be in possession of a research Master's degree, or be in the process of completing requirements for such a degree. Should be South African citizens or permanent residents

Level of Study: Postgraduate

Type: Scholarship

Value: ZAR 240,000

Length of Study: The VUA-NRF Desmond Tutu Training Programme provides funding for up to four (4) years of study, depending on satisfactory progress each year

Country of Study: South Africa

Application Procedure: Check website for more details

Closing Date: 17 July

Contributor: Vrije Universiteit Amsterdam (VUA)

Additional Information: scholarship-positions.com/vuuniversity-amsterdam-nrf-desmond-tutu-doctoral-scholarshipsfor-south-african-citizens-2015/2015/06/13/

\section{For further information contact:}

Email: danielle.nel@nrf.ac.za

\section{National Science Foundation (NSF)}

4201 Wilson Boulevard, Arlington, VA 22230, United States of America.
Tel:
Email:
(1) 7032925111
Website:
info@nsf.gov
Contact:
www.nsf.gov
Division Director

The National Science Foundation (NSF) supports research in the areas of geology, geophysics, geochemistry, paleobiology and hydrology, including interdisciplinary or multidisciplinary proposals that may involve one or more of these disciplines.

\section{Cultural Anthropology Program Senior Research Awards}

Purpose: The primary objective of the Cultural Anthropology Program is to support fundamental, systematic anthropological research and training to increase understanding of the causes, consequences, and complexities of human social and cultural variability

Eligibility: The categories of proposers eligible to submit proposals to the National Science Foundation are identified in the NSF Proposal \& Award Policies \& Procedures Guide

Level of Study: Graduate

Type: Grant

Frequency: Annual

Country of Study: Any country

Closing Date: 15 August

Funding: Foundation

Additional Information: The Cultural Anthropology Program cannot support research that takes as its primary objective improved clinical practice, applied policy, or other immediate application www.nsf.gov/funding/pgm_summ. jsp?pims_id $=505513$

\section{For further information contact:}

Email: jmantz@nsf.gov

\section{Directorate for Education and Human Resources Core Research}

Purpose: The ECR program places emphasis on the rigorous development of theory and accumulation of knowledge to inform efforts to address challenges in STEM interest, learning, and participation, for all groups and all ages in formal and informal settings. This emphasis includes research on advancing evaluative methodologies to support research efforts funded through ECR

Level of Study: Graduate

Type: Research

Frequency: Annual

Country of Study: Any country

Closing Date: 24 January

Funding: Foundation

Additional Information: 1. Level 1 and Level 2 proposals have a maximum grant duration of three years. 2. Level 3 proposals have a maximum grant duration of five years. ECR Proposals may fall within three levels of funding. Level 1 Proposals: have a maximum award size of US $\$ 5,00,000$. Synthesis proposals may only be budgeted at Level 1 or 2 . Level 2 Proposals: have a maximum award size of US $\$ 1,500,000$. 
Synthesis proposals may only be budgeted at Level 1 or 2. Level 3 Proposals: have a maximum award size of US $\$ 2,500,000$ www.nsf.gov/funding/pgm_summ.jsp?pims $\mathrm{id}=504924$

\section{For further information contact:}

Email: ECR@nsf.gov

\section{Enabling Discovery through GEnomic Tools (EDGE)}

Purpose: The Enabling Discovery through GEnomic Tools (EDGE) track was previously a component of the Division of Integrative Organismal Systems (IOS) Core Programs solicitation (NSF 16-505). Submission of letters of intent or preliminary proposals is not required. Only full proposals should be submitted in response to this solicitation. There is no annual limit to the number of proposals submitted per PI or co-PI in response to this solicitation

Eligibility: Institutions of Higher Education (IHEs) - Twoand four-year IHEs (including community colleges) accredited in, and having a campus located in the United States, acting on behalf of their faculty members. Special Instructions for International Branch Campuses of United States IHEs: If the proposal includes funding to be provided to an international branch campus of a United States institution of higher education (including through use of subawards and consultant arrangements), the proposer must explain the benefit(s) to the project of performance at the international branch campus, and justify why the project activities cannot be performed at the United States campus. Non-profit, non-academic organizations: Independent museums, observatories, research labs, professional societies and similar organizations in the United States associated with educational or research activities

Level of Study: Graduate

Type: Award

Frequency: Annual

Country of Study: Any country

Application Procedure: Step 1: Download a Grant Application Package and Application Instructions link and enter the funding opportunity number, (the program solicitation number without the NSF prefix) and press the Download Package button

Closing Date: 7 February

Funding: Private

Additional Information: For this solicitation, EDGE proposals do not require submission of a letter of intent or preliminary proposals. Additional merit review considerations and special review criteria can be found in section VI of this solicitation www.nsf.gov/pubs/2020/nsf20532/nsf20532.htm

\section{For further information contact:}

2415, Eisenhower Avenue., Alexandria, VA 22314, United States of America.

Email: nsfpubs@nsf.gov

\section{Faculty Early Career Development Program (CAREER)}

Purpose: Each year NSF selects nominees for the Presidential Early Career Awards for Scientists and Engineers (PECASE) from among the most meritorious recent CAREER awardees. These awards foster innovative developments in science and technology, increase awareness of careers in science and engineering, give recognition to the scientific missions of the participating agencies, enhance connections between fundamental research and national goals

Level of Study: Foundation programme

Type: Fellowships, operating grants

Frequency: Annual

Country of Study: Any country

Closing Date: 17 July

Funding: Foundation

Additional Information: www.nsf.gov/funding/pgm summ.jsp?pims_id=503214

\section{Macrosystems Biology and NEON-Enabled Science (MSB-NES)}

Purpose: The Macrosystems Biology and NEON-Enabled Science (MSB-NES): Research on Biological Systems at Regional to Continental Scales program will support quantitative, interdisciplinary, systems-oriented research on biosphere processes and their complex interactions with climate, land use, and invasive species at regional to continental scales as well as training activities to enable groups to conduct Macrosystems Biology and NEON-Enabled Science research

Eligibility: Proposals may only be submitted by the following: Institutions of Higher Education (IHEs) - Two- and four-year IHEs (including community colleges) accredited in, and having a campus located in the United States, acting on behalf of their faculty members. Special Instructions for International Branch Campuses of United States IHEs: If the proposal includes funding to be provided to an international branch campus of a United States institution of higher education (including through use of subawards and consultant arrangements), the proposer must explain the benefit(s) to the project of performance at the international branch campus, and justify why the project activities cannot be performed at the United States campus. Non-profit, non-academic organizations: Independent 
museums, observatories, research labs, professional societies and similar organizations in the United States associated with educational or research activities

Level of Study: Graduate

Type: Award

Value: US\$900,000

Frequency: Annual

Country of Study: Any country

Closing Date: 25 February

Funding: Private

Additional Information: www.nsf.gov/bfa/dias/policy/ merit_review/ www.nsf.gov/funding/pgm_summ.jsp?pims $\mathrm{id}=5 \overline{03425}$

\section{For further information contact:}

Email: mbinford@nsf.gov

\section{National Science Foundation Research Traineeship (NRT) Program}

Purpose: The NSF Research Traineeship (NRT) program is designed to encourage the development and implementation of bold and potentially transformative models for science, engineering and mathematics (STEM) graduate education training. The NRT program seeks proposals that explore ways for graduate students in research-based master's and doctoral degree programs to develop the skills, knowledge, and competencies needed to pursue a range of STEM careers

Level of Study: Graduate

Type: Grant

Frequency: Annual

Country of Study: Any country

Closing Date: 6 February

Funding: Foundation

Additional Information: www.nsf.gov/funding/pgm summ.jsp?pims_id=505015

For further information contact:

Email:1regassa@nsf.gov

\section{Robert Noyce Teacher Scholarship Program}

Purpose: The program invites creative and innovative proposals that address the critical need for recruiting and preparing highly effective elementary and secondary science and mathematics teachers in high-need local educational agencies Level of Study: Graduate, Foundation programme Type: Scholarship

Frequency: Annual

Country of Study: Any country
Closing Date: 27 August

Funding: Private

Additional Information: Capacity Building proposals are accepted from proposers intending to develop a future Track 1,2 , or 3 proposal www.nsf.gov/funding/pgm_summ.jsp? pims_id $=5733$

\section{For further information contact:}

Email: rturley@nsf.gov

\section{Scalable Parallelism in the Extreme (SPX)}

Purpose: The Scalable Parallelism in the Extreme (SPX) program aims to support research addressing the challenges of increasing performance in this modern era of parallel computing. This will require a collaborative effort among researchers in multiple areas, from services and applications down to micro-architecture

Eligibility: Proposals may only be submitted by the following: 1. Institutions of Higher Education (IHEs) - Two- and four-year IHEs (including community colleges) accredited in, and having a campus located in the United States, acting on behalf of their faculty members. 2. Non-profit, non-academic organizations: Independent museums, observatories, research labs, professional societies and similar organizations in the United States associated with educational or research activities

Level of Study: Graduate

Type: Grants, work-study (not just grants)

Frequency: Annual

Country of Study: Any country

Closing Date: 17 January

Funding: Private

Additional Information: This limit on the number of proposals per PI, co-PI or Senior Personnel applies only to this SPX program solicitation www.nsf.gov/pubs/2019/nsf19505/ nsf19505.htm

For further information contact:

Email: abanerje@nsf.gov

\section{National Sea Grant College}

1315 East-West Highway, Silver Spring, MD 20910, United States of America.

Tel: $\quad$ (1) 3017341066

Email: sgfellow@ucsd.edu

Website: www.seagrant.noaa.gov

Contact: Jim Eckman, Director 
Sea Grant is a nationwide network administered through the National Oceanic and Atmospheric Administration (NOAA) of 30 university-based programmes that work with coastal communities. The organizations research and programmes promote better understanding, conservation and use of America's coastal resources. In short, Sea Grant is science serving America's coasts.

\section{Sea Grant/NOAA Fisheries Graduate Fellowship}

Purpose: To financially support and encourage qualified applicants to pursue careers in either population dynamics and stock assessment or in marine resource economics and also to increase available expertise related to these fields Eligibility: Applicants have to be $\mathrm{PhD}$ students in population dynamics or marine resource economics or related disciplines concentrating on the conservation and management of living marine resources

Level of Study: Doctorate

Type: Fellowship

Value: US\$43,500 per year

Length of Study: 2 years

Frequency: Annual

Closing Date: 26 January

Funding: Government

For further information contact:

Email: terry.smith@noaa.gov

\section{National Sun Yat-Sen University (NSYSU)}

70 Lien-hai Road, Kaohsiung 804, Taiwan.

Tel: $\quad$ (886) 75252633

Website: www.oia.nsysu.edu.tw

National Sun Yat-Sen University (NSYSU) was founded in 1924 and is located alongside the Hsitzu Bay of Kaohsiung city. It is the leading international academic institution in Southern Taiwan with a vision to provide diverse and comprehensive higher education.

\section{National Sun Yat-sen University International Fellowship}

Purpose: To pursue academic excellence combining theory and practice
Eligibility: Open to candidates who are pursuing their Master's or Doctoral degrees

Level of Study: Doctorate, Postgraduate

Type: Fellowships

Value: Varies

Length of Study: 2-3 months

Frequency: Annual

Application Procedure: Applications along with a curriculum vitae, research proposal, name of the corresponding member in the Kuroshio Research Group and 2 letters of recommendation must be mailed

Additional Information: "Recommendation to Kuroshio Application" must appear as the subject line

For further information contact:

Email: keryea@mail.nsysu.edu.tw

\section{National Tax Association}

\section{Tax Institute of America Doctoral Dissertations in Government and Taxation}

Subjects: Finance

Purpose: To award original, innovative, clear and analytical dissertations written by scholars and practitioners of government finance.

Eligibility: The award will be granted to exceptional dissertations written by scholars and practitioners of government finance.

Type: Award

Value: The winning entry will receive US\$2,000 and the opportunity to publish a paper based on the dissertation in the National Tax Journal. There will also be two honorable mentions of US\$1,000 each for outstanding entries.

Country of Study: Any country

Closing Date: 15 June

Additional Information: www.ntanet.org

\section{National Tour Association}

\section{National Tour Association (NTA) Luray Caverns Graduate Research Scholarship}

Purpose: To aid graduate students who are conducting tourism-related research

Eligibility: 1. Applicants can be permanent residents of any country but must be enrolled at an accredited United States or Canadian four-year postsecondary institution. 2. They must be entering or returning graduate students who are conducting 
research that focuses on tourism. They must have a proven commitment to the tourism industry, and must have a GPA of 3.0 or higher on a four-point scale. Selection is based on the strength of the research project

Level of Study: Graduate

Type: Scholarship

Frequency: Annual

Country of Study: Any country

Application Procedure: Applications are available online. An application form, proof of residency, a personal essay, a resume, a research proposal, an official transcript and one letter of recommendation are required. Check the sponsor website for further information. www.tourismcares.org/ academic-scholarships/

Closing Date: 3 April

Funding: Private

Additional Information: www.chegg.com/scholarships/ national-tour-associationluray-caverns-graduate-research-scholar ship-2345

\section{For further information contact:}

Email: info@tourismcares.org

\section{National Union of Teachers (NUT)}

Hamilton House, Mabledon Place, London, WC1H 9BD, United Kingdom.

Tel: (44) 2073886191

Email: a.bush@nut.org.uk

Website: www.teachers.org.uk

Contact: Ms Angela Bush

\section{National Union of Teachers Page Scholarship}

Purpose: To promote the exchange of educational ideas between Britain and America

Eligibility: Open to teaching members of the NUT aged 2560 years, although $25-55$ is preferred

Level of Study: Graduate

Type: Scholarship

Value: Each up to $£ 1,700$ pro rata daily rate with complete hospitality in the United States of America provided by the English- Speaking Union of the United States of America Length of Study: 2 weeks. The scholarship must be taken during the American academic year, which is September-May Frequency: Annual

Country of Study: United States of America

Application Procedure: Applicants must complete an application form. An outline and synopsis of the project must accompany the form along with a curriculum vitae and scholastic and personal testimonials

No. of awards offered: 100

Funding: Private

No. of awards given last year: 2

No. of applicants last year: 100

Additional Information: It is a discontinued award type. The scholarship is limited to the individual teacher and neither the spouse nor partner can be included in the travel, accommodation or study arrangements. Recipients are required to report on their visit to teacher groups and educational meetings in the United States and on their return home

\section{For further information contact:}

Tel: $\quad$ (44) 18122779670

Fax: (44) 2073886191

\section{National University of Ireland Galway}

Postgraduate Admission Office, University Road, Galway, Ireland.

Tel:

$$
\text { (353) } 91524411
$$

Email: info@it.nuigalway.ie

Website: www.nuigalway.ie

Contact: Mairead Faherty

\section{Charles Parsons Energy Research Award}

Purpose: To focus on investigation and optimization of electron transfer reactions in biological fuel cells that can generate energy from diverse substrates. To focus the research on applications of pure- and mixed-culture microbial fuel cells, and biocatalytic enzyme-based fuel cells

Eligibility: Open to engineering graduates

Level of Study: Doctorate

Type: Research award

Value: Salary scale $€ 55,000-80,486$ per year for researchers, stipend of $€ 18,000$ per year plus tuition fees for PhD studentship and undergraduate engineering students $€ 1,500$ per month Application Procedure: Applicants should include a curriculum vitae and the names of two academic referees

Closing Date: October

Additional Information: The research will involve liaison with international collaborators, bench research and reporting. To this end, good inter-personal, written communication and networking skills are advantageous

\section{For further information contact:}

Email: donal.leech@nuigalway.ie 


\section{Hardiman PhD Scholarships}

Eligibility: 1. Successful applicants will be expected to have a first or upper second class honours primary degree or equivalent. 2. Applications will not be accepted from persons currently registered as $\mathrm{PhD}$ students. 3. English Language Requirements - please go to this webpage www.nuigalway. ie/international-students/entry-requirements/

Level of Study: Postgraduate

Type: Scholarship

Value: $€ 16,000$ p.a. plus fees

Length of Study: 4 years

Application Procedure: Applicants must read Applicant's Guide: (www.nuigalway.ie/media/hardiman/files/ApplicantsGuide-2020.docx) prior to completing the application form

Closing Date: 14 February

Additional Information: www.nuigalway.ie/hardimanscholarships/

\section{For further information contact:}

Email: hrscholar@nuigalway.ie

\section{PhD Student Scholarship in Atmospheric Science}

Purpose: To study the effect of ambient relative humidity on aerosol radiative parameters: aerosol light scattering coefficient and aerosol absorption coefficient

Eligibility: Open to candidates who have obtained a good Honours Degree (grade 2.1 at least) in physics or in a cognate subject

Level of Study: Doctorate

Type: Scholarship

Value: stipend and tuition fees

Length of Study: 3 years

Country of Study: Ireland

Application Procedure: Applicants must submit a covering letter, curriculum vitae and the names of at least two referees

\section{For further information contact:}

Tel: $\quad$ (353) 91492704

Fax: (353) 91495515

Email: gerard.jennings@nuigalway.ie

\section{Student Research Scholarship in Occupational Hygiene}

Purpose: To enhance GSK's exposure assessment strategy, to look at current occupational hygiene data collected from across all GSK sites and to apply Bayesian statistics to optimize the exposure assessment strategy
Eligibility: Open to candidates who have obtained an Honours Degree (2.1 minimum) in a science or engineering discipline. Ideally, the candidate should have a sound understanding of mathematics/statistics, combined with an understanding of exposure assessment

Level of Study: Postgraduate

Type: Scholarship

Value: Monthly stipend

Country of Study: Ireland

Application Procedure: Applicants must submit a covering letter, a curriculum vitae and the names of at least two referees

Closing Date: 31 August

Contributor: GlaxoSmithKline (GSK)

\section{For further information contact:}

Department of Experimental Physics, National University of Ireland, University Road, Galway, Ireland.

Email: marie.coggins@nuigalway.ie

\section{Taught Postgraduate Scholarships}

Purpose: NUI Galway has established a Postgraduate Scholarship Scheme to support and facilitate students wishing to register for a Fulltime Taught Postgraduate Masters programme Eligibility: In order to be eligible for the award of a scholarship, students must: 1 . Have submitted a valid online scholarship application form by the deadline; 2 . Be registered in Year 1 of a Fulltime Taught Masters programme for the academic year subsequent to the scholarship application (repeat students are not eligible to apply); 3. Have attained a first class honours (or equivalent) in a Level 8 primary degree. Level of Study: Postgraduate

Type: Scholarship

Value: The total value of the Scholarship will be $€ 1,500$ per student

Application Procedure: Applications must be made using the online application form

Closing Date: 14 August

Additional Information: www.nuigalway.ie/media/registry/ admissions/files/Scholarship_criteria.pdf

\section{National University of Ireland, Maynooth}

Research Support Office, Auxilia House, North Campus, NUI, Maynooth, Co. Kildare, Ireland.

Tel: (353) 17086000

Email: research.support@nuim.ie

Website: www.nuim.ie 
Following two centuries of internationally renowned scholarly activity on the Maynooth campus, the National University of Ireland, Maynooth was established under the 1997 Universities Act as an autonomous member of the federal structure known as the National University of Ireland. With approximately 8,400 registered students, NUI, Maynooth has 26 academic departments which are organized into three Faculties: Arts, Celtic Studies and Philosophy; Science and Engineering; and Social Sciences. Building on a tradition of scholarship and excellence in all aspects of its teaching, learning, and research activities, within the liberal arts and sciences tradition NUI, Maynooth is committed to being a first-class research-led centre of learning and academic discovery.

\section{John and Pat Hume Research Scholarships}

Purpose: To build on excellence in areas across the arts, humanities, social sciences, sciences and engineering

Eligibility: Applicants must have a First or Upper SecondClass Honours Primary Degree (or equivalent) from Ireland, the European Union or from any overseas university and intend to pursue a $\mathrm{PhD}$ degree at the University. Those who have commenced a research degree at NUI Maynooth prior to application will not be eligible

Level of Study: Postgraduate, Research

Type: Scholarship

Value: $€ 5,000$ per year plus payment of fees at European Union level. In some cases an additional fund of $€ 3,000$ is also provided to the student researcher for activities undertaken in support of the Department including tutorials and laboratory demonstration

Length of Study: Up to 4 years

Frequency: Annual

Study Establishment: NUI Maynooth

Country of Study: Ireland

Application Procedure: Applicants must first make contact with a NUI Maynooth department or centre to discuss their suitability for a $\mathrm{PhD}$ programme. A list of departmental contacts is available on the website. Application for the scholarship can then be filed

Closing Date: May

No. of awards given last year: 30

Additional Information: Supplement the scholarship with an additional $€ 3,000$ for tutorial or demonstrating duties www. maynoothuniversity.ie/study-maynooth/postgraduate-studies/ fees-funding-scholarships/john-and-pat-hume-doctoral-awards

\section{For further information contact:}

Tel: $\quad$ (353) 17086018

Fax: (353) 17083359

Email: pgdean@nuim.ie

\section{Maynooth University Teaching Studentships}

Purpose: Funded student teaching assistant opportunities are offered across a range of disciplines at Maynooth University. Successful applicants will commence PhD Doctoral studies at Maynooth University in the Autumn semester and will have 5 years to complete their $\mathrm{PhD}$

Level of Study: Postgraduate, PhD research

Type: Scholarship

Value: 1. Full annual tuition fees support (approximately $€ 6,200$ per annum); 2 . A fixed stipend of $€ 9,007$ per annum

Length of Study: 5 years

Additional Information: www.maynoothuniversity.ie/ study-maynooth/postgraduate-studies/fees-funding-scholar ships/maynooth-university-teaching-studentship

\section{Taught Master's Scholarships}

Eligibility: 1. 60 Taught Master's scholarships of $€ 2000$ each will be awarded to student across all disciplines in recognition of academic excellence. 2. All applicants must have achieved a minimum 2.1 honours undergraduate degree. 3. Open to both EU and Non-EU applicants. 4. Graduates or current students of PhD or Master's programmes are not eligible to apply. Prospective students interested in research programmes should apply instead for the Maynooth University John and Pat Hume Doctoral Research Awards.

Level of Study: Postgraduate, $\mathrm{PhD}$ research

Type: Scholarship

Value: US\$2,000

Application Procedure: Apply online via www.maynoothu niversity.ie/study-maynooth/postgraduatestudies/fees-fundingscholarships

Closing Date: 15 June

Additional Information: www.maynoothuniversity.ie/ study-maynooth/postgraduate-studies/fees-funding-scholar ships/taught-masters-scholarships

For further information contact:

Tel: (353) 17083990

Email: tmscholarships@mu.ie

\section{National University of Singapore (NUS)}

21 Lower Kent Ridge Road, 119077 Singapore.

Tel: $\quad$ (65) 65166666

Email: gradenquiry@nus.edu.sg

Website: www.nus.edu.sg 
NUS aspires to be a dynamic connected knowledge community imbued with a no walls culture that promotes the free flow of talent and ideas. Individual members of our community enjoy access to diverse opportunities for intellectual and professional growth and in twin add value to NUS becoming a global knowledge enterprise.

\section{Asian Development Bank-Japan Scholarship Program}

Purpose: To find further study in public policy implementation

Eligibility: Open to residents of Asian Development Bank member countries currently enroled at NUS. Upon completion of their study programmes, scholars are expected to contribute to the economic and social development of their home countries. Check website for further details

Level of Study: Postgraduate

Type: Scholarship

Value: S\$250 per semester (one-time book allowance), tuition, health insurance, examination and other approved fees. Cost of travel from home country to Singapore on award of the scholarship and from Singapore to home country on graduation

Length of Study: 2 years for Master in public policy

Frequency: Annual

Study Establishment: Lee Kuan Yew School of Public Policy, National University of Singapore

Country of Study: Singapore

Application Procedure: Application form with 3 photographs attached, certificate of citizenship (or a copy of your valid passport), research and/or work experience, two confidential letters of recommendation

No. of awards offered: 350

Closing Date: 12 July

Funding: Government

Contributor: Government

No. of awards given last year: 3

No. of applicants last year: 350

Additional Information: www.ait.ac.th/admissions/scholar ships/asian-development-bank-japan-scholarship-program/

\section{Law/Faculty Graduate Scholarship (FGS)}

Purpose: To reward an outstanding student of the faculty of Law

Eligibility: Outstanding applicants of any nationality (including Singapore citizens and permanent residents) may be awarded the FGS to pursue the LLM coursework degrees: LLM, LLM (Asian Legal Studies), LLM (Corporate \& Financial Services Law), LLM (Intellectual Property \& Technology
Law), LLM (International \& Comparative Law), LLM (Maritime Law)

Level of Study: Postgraduate

Type: Scholarship

Value: The scholarship will cover tuition fees

Frequency: Annual

Study Establishment: National University of Singapore

Country of Study: Singapore

Additional Information: Terms of award are subject to change without prior notice

\section{Lee Kuan Yew School of Public Policy Graduate Scholarships (LKYSPPS)}

Purpose: To find further study in public policy and administration implementation

Eligibility: Open to all nationalities (except Singapore)

Level of Study: Postgraduate

Type: Scholarship

Value: A monthly stipend, a one-time book allowance, a one-time settling-in allowance, shared housing, tuition, health insurance, examination and other approved fees, cost of travel from home country to Singapore on award of the scholarship and from Singapore to home country on graduation

Length of Study: 1 year (for public administration) and 2 years (for public policy)

Frequency: Annual

Study Establishment: Lee Kuan Yew School of Public Policy, National University of Singapore

Country of Study: Singapore

Application Procedure: Apply online

Funding: Government

Contributor: Government

For further information contact:

Email: LKYSPPmpp@nus.edu.sg

\section{Master of Business Administration Programme}

Application Procedure: Applicants must complete an application form supplying US\$15 fee

Closing Date: 1 April

\section{For further information contact:}

Graduate School of Business, MBA Programme, FBA2, Level 5, Room 6, 17 Law Link, 117592 Singapore.

Tel: $\quad$ (65) 68746149

Fax: (65) 67782681

Email: fbagrad@nus.edu.sg 


\section{National University of Singapore Design Technology Institute Scholarship}

Eligibility: Open to all nationalities with good Bachelor's degree with Honours in Engineering or Science

Level of Study: Postgraduate

Type: Scholarship

Value: A monthly stipend $\mathrm{S} \$ 1,500$ with a possible monthly top-up of S\$500 and all approved NUS fees

Length of Study: 2 years

Frequency: Annual

Study Establishment: National University of Singapore

Country of Study: Singapore

Closing Date: November

Additional Information: DTI Scholars who are international students will be required to serve a 2 years bond in Singapore upon graduation

\section{For further information contact:}

Tel: $\quad$ (65) 68741227

Fax: (65) 68732175

Email: dtibox@nus.edu.sg

\section{Singapore-MIT Alliance Graduate Fellowship}

Purpose: The SMA Graduate Fellowship is established by the Singapore Ministry of Education in January 2009 to attract the best and most talented PhD students from Singapore, the region and beyond, and educate them to be future leaders in the areas of science and technology. The selection of candidates will take place twice a year, in time for the start of the semesters in August and January

Eligibility: The Scholarships are open to students of all nationalities who gain admission to any $\mathrm{PhD}$ programme at the University whose research interest fits within one or more of the projects currently being carried out in one of the SMART Interdisciplinary Research Groups (IRGs)

Level of Study: Graduate, Postgraduate

Type: Fellowship

Value: A monthly stipend of Singaporean $\$ \$ 3,200$; Tuition fees at NUS; and Scholarship allowance of up to $\$ \$ 12,000$ to help cover the expenses associated with a 6-month research residency at MIT

Length of Study: The award is tenable for 1 year in the first instance; but subject to the scholar's satisfactory progress, it may be renewed each semester. The maximum period of award is 4 years

Frequency: Annual

Study Establishment: National University of Singapore and Nanyang Technological University

Country of Study: Singapore
Application Procedure: Applicants must apply separately to both MIT and NUS/NTU for the dual degrees and only to NUS or NTU for direct PhD degree; applicants must also apply directly to SMA for an SMA Graduate Fellowship

No. of awards offered: 120

Closing Date: March

Funding: Government

Contributor: A*Star, Economic and Development Board (EDB), Ministry of Education (MOE), National University of Singapore (NUS) and Nanyang Technological University (NTU)

No. of applicants last year: 120

Additional Information: smart.mit.edu/fellowships/forgraduates-smart-graduates

\section{For further information contact:}

Tel: $\quad$ (65) 65164787

Fax: (65) 67752920

Email: smart@nus.edu.sg

\section{Natural Environment Research Council (NERC)}

Polaris House, North Star Avenue, Wiltshire, Swindon, SN2 1EU, United Kingdom.

Tel: $\quad$ (44) 1793442644

Email: stag@nerc.ac.uk

Website: www.nerc.ac.uk/funding

Contact: Studentships \& Training Awards Group (STAG)

The Natural Environment Research Council (NERC) is one of the seven United Kingdom Research Councils that fund and manage research in the United Kingdom. NERC is the leading body in the United Kingdom for research, survey, monitoring and training in the environmental sciences. NERC supports research and training in universities and in its own centres, surveys and units.

\section{Natural Environment Research Council Independent Research Fellowships (IRF)}

Purpose: To develop scientific leadership among the most promising early-career environmental scientists, by giving all Fellows 5 year's support, which will allow them sufficient time to develop their research programmes, and to establish international recognition

Eligibility: Open to any nationality, and may be held in any area of the NERC remit, but the fellowship must be based at 
an eligible United Kingdom Research Organization. Applicants may not have a permanent academic position in a university or equivalent organization. Applicants must expect to submit their $\mathrm{PhD}$ thesis before the fellowship interview would take place (April following the closing date) and, if successful, would not be able to take up the fellowship until the intent to award the $\mathrm{PhD}$ has been confirmed by the awarding university. Applicants may have up to a maximum of 8 years of full-time postdoctoral research experience between the $\mathrm{PhD}$ certificate date and the closing date of the fellowship competition to which they are applying. The eight year window is based on full-time working. Where applicants have worked part-time or had research career breaks, the eight year window would be extended accordingly

Level of Study: Research

Type: Fellowship

Value: Includes $80 \%$ of the full economic cost (FEC) of the proposal. NERC will provide funding for the fellow

Length of Study: 5 years

Frequency: Annual

Study Establishment: Universities and other approved research institutes

Country of Study: United Kingdom

Application Procedure: Please refer to the Research Grants and Fellowships Handbook at www.nerc.ac.uk/funding/avail able/fellowships/apply/

Closing Date: October

Funding: Government

No. of awards given last year: 14

Additional Information: microsites.ncl.ac.uk/nubsstaffblog/ 2019/06/25/nerc-independent-research-fellowships/

\section{For further information contact:}

Email: Fellowships@nerc.ac.uk

\section{Natural Environment Research Council Research Grants}

Purpose: To support a specific investigation in which the applicant will be engaged personally, to enter promising new or modified fields of research, or to take advantage of developments in apparatus offering improved techniques in promising lines of research already established

Eligibility: Open to research workers ordinarily resident in the United Kingdom who are also members of the academic staff of universities, colleges and similar institutions within the United Kingdom recognised by the NERC. Research assistants and technicians are not eligible to apply. Holders of Research Council Fellowships at an Institute of Higher Education are eligible to apply for research grants

Level of Study: Postdoctorate, Professional development
Type: Grant

Value: The Standard Research Grant offers amounts over $£ 30,000$, for periods not usually in excess of three years. The Small Research Grant offers a more rapid response for applications costing £2,000-30,000. Applications for less than $£ 2,000$ will not be accepted. The new investigator scheme offers up to the $£ 50,000$

Frequency: Throughout the year

Study Establishment: Any approved Institute of Higher Education in the United Kingdom

Country of Study: United Kingdom

Application Procedure: Applicants must complete an application form, available on request. Application forms and further information can be found on the NERC website

Closing Date: 1 October

Funding: Government

No. of awards given last year: 307

For further information contact:

Email: researchcareers@nerc.ac.uk

\section{Natural Hazards Center-University of Colorado}

482 UCB, Boulder, CO 80309-0482, United States of America.

Tel:

(1) 3034926818

Email:_hazctr@colorado.edu

Website: www.colorado.edu/hazards

The mission of the Natural Hazards Center at the University of Colorado at Boulder is to advance and communicate knowledge on hazards mitigation and disaster preparedness, response and recovery. Using an all hazards and interdisciplinary framework, the Center fosters information- sharing and integration of activities among researchers, practitioners and policy makers from around the world, supports and conducts research and provides educational opportunities for the next generation of hazards scholars and professionals.

\section{Dissertation Fellowship in Hazards, Risks, and Disaster}

Purpose: To provide financial support for research that is crucial to advancing the knowledge in the hazards field, as well as ensure that the next generation of interdisciplinary hazards professional has a source of financial and academic support to foster sound development 
Eligibility: Open to candidates who already have a dissertation at an institution in the United States. Non-United States citizens may apply as long as the Doctorate degree will be granted by a United States institution

Level of Study: Postgraduate

Type: Fellowships

Value: US\$10,000

Frequency: Annual

Country of Study: United States of America

Application Procedure: The applicant must submit a curriculum vitae along with a dissertation summary

Closing Date: September

Additional Information: freestudiesabroad.blogspot.com/ 2006/06/dissertation-fellowship-in-hazards.html

For further information contact:

Email: periship@riskinstitute.org

\section{Natural Sciences and Engineering Research Council of Canada (NSERC)}

350 Albert Street, 16th floor, Ottawa, ON K1A 1H5, Canada.

Tel: $\quad$ (1) 6139954273

Email: claire.mcaneney@nserc-crsng.gc.ca

Website: www.nserc.ca

Contact: Corporate Account Executive

NSERC is Canada's instrument for promoting and supporting university research in the natural sciences and engineering, other than the health sciences. NSERC supports both basic university research through discovery grants and project, research through partnerships among universities, governments, and the private sector as well as the advanced training of highly qualified people.

\section{Aboriginal Ambassadors in the Natural Sciences and Engineering Award}

Purpose: The Aboriginal Ambassadors in the Natural Sciences and Engineering (AANSE) award aims to engage Aboriginal students and fellows in promoting interest and participation in the natural sciences and engineering by visiting Canada's Aboriginal communities and schools and sharing their research and education experiences or participating in science promotion events and activities

Eligibility: Open to Canadian citizen or permanent resident of Canada
Level of Study: Postgraduate

Type: Award

Value: Up to $C \$ 5,000$

Country of Study: Canada

Application Procedure: Applications must be submitted electronically using the Secure Submissions for NSERC's Innovative Collaborations and Science Promotion Programs (competitions.nserc-crsng.gc.ca/500001/default.aspx)

Additional Information: NSERC will notify you of the decision on your application within one month of receiving it. For more details, please mail to ambassadors@nserc-crsng. gc.ca www.nserc-crsng.gc.ca/Students-Etudiants/AboriginalAutochtones_eng.asp

\section{For further information contact:}

Email: ambassadors@nserc-crsng.gc.ca

\section{Canada Graduate Scholarships - Michael Smith Foreign Study Supplements Program}

Purpose: The Canada Graduate Scholarships - Michael Smith Foreign Study Supplements (CGS-MSFSS) Program supports high calibre Canadian graduate students in building global linkages and international networks through the pursuit of exceptional research experiences at research institutions abroad

Eligibility: Open to Canadian citizen or permanent resident of Canada

Level of Study: Postgraduate

Type: Award

Value: Up to $\mathrm{C} \$ 6,000$ for a period of research study abroad

Length of Study: 6 months

Country of Study: Canada

Application Procedure: Online application procedure. For details, contact schol@nserc-crsng.gc.ca

Closing Date: 10 October

Additional Information: For more information, contact CGSMSFSS@cihr-irsc.gc.ca www.nserc-crsng.gc.ca/Stud ents-Etudiants/PG-CS/CGSForeignStudy-BESCEtudeEtra nger_eng.asp

\section{For further information contact:}

Email: cgsma@cihr-irsc.gc.ca

\section{Canada Graduate Scholarships-Master's (CGS M) Program}

Purpose: The objective of the Canada Graduate Scholarships-Master's (CGS M) Program is to help develop research skills and assist in the training of highly qualified 
personnel by supporting students who demonstrate a high standard of achievement in undergraduate and early graduate studies

Eligibility: Open to Canadian citizen or permanent resident of Canada

Level of Study: Postgraduate

Type: Award

Value: $\mathrm{C} \$ 17,500$

Length of Study: 1 year

Country of Study: Canada

Application Procedure: Application/Canadian common CV

Closing Date: 1 December

Additional Information: Refer to the Tri-Agency Harmonization of the Canada Graduate Scholarships page www.nserccrsng.gc.ca/Students-Etudiants/CGSHarmonization-Harmon izationBESC eng.asp www.nserc-crsng.gc.ca/Students-Etud iants/PG-CS/CGSM-BESCM eng.asp

\section{For further information contact:}

Email: Schol@nserc-crsng.gc.ca

\section{Canada Postgraduate Scholarships (PGS)}

Eligibility: Open to a Canadian citizen or a permanent citizen of Canada, with a university degree in science or engineering, intending to pursue year full-time graduate study and research at the Master's or Doctorate level in one of the areas supported by NSERC with a first-class average in each of the last two completed years of study

Level of Study: Postgraduate

Type: Fellowship

Value: $C \$ 17,300$ (Masters) per year for 1 year and $C \$ 21,000$

(Doctoral) per year for a period of 2-3 years

Length of Study: 1 year

Frequency: Annual

Country of Study: Canada

Application Procedure: Check website for further details

Closing Date: 15 October

Contributor: Natural Sciences and Engineering Research Council of Canada (NSERC)

\section{For further information contact:}

National Sciences and Engineering Research Council of Canada (NSERC), Scholarships and Fellowships Division, 350 Albert Street (for courier mailings, add 10th Floor), Ottawa, ON K1A 1H5, Canada.

Fax: (1) 6139962589

Email: schol@nserc.ca

\section{Defence Research and Development Canada Postgraduate Scholarship Supplements}

Purpose: To encourage and support graduates to carry out research of interest to DRDC; to increase contact between DRDC researchers and those at Canadian universities; and to foster graduate training potential candidates for possible employment at DRDC

Eligibility: Open to candidates possessing a CGS, PGS or IPS award

Level of Study: Postgraduate

Type: Scholarship

Value: $C \$ 5,000$ per year

Length of Study: 2 years

Frequency: Annual

Country of Study: Canada

Application Procedure: Applicants must submit a copy Notification of Award document from NSERC, a copy of successful scholarship application (Form 200), and a statement of interest in R\&D for defence/national security. Check website for further details

Closing Date: 1 June

Contributor: Defence Research and Development Canada

\section{For further information contact:}

DRDC Postgraduate Scholarship Supplements Program, Department of National Defence, 305 Rideau Street, Ottawa, ON K1N 5Y6, Canada.

Tel: $\quad$ (1) 6139920563

Fax: (1) 6139967063

Email: hr-rh@drdc-rddc.gc.ca

\section{NSERC Postgraduate Scholarships-Doctoral program}

Purpose: The NSERC Postgraduate Scholarships - Doctoral (PGS D) program provides financial support to high-calibre scholars who are engaged in an eligible doctoral program (see Eligibility Criteria for Students and Fellows) in the natural sciences or engineering. This support allows these scholars to fully concentrate on their studies and seek out the best research mentors in their chosen fields.

Eligibility: 1. be a Canadian citizen or a permanent resident of Canada, as of the application deadline date; 2 . have completed no more than 24 months of full-time study in their doctoral program by December 31 of the year of application (no more than 36 months if transferred directly from Bachelors to a $\mathrm{PhD}$ or enrolled in a joint program, e.g., $\mathrm{MD} / \mathrm{PhD}$, $\mathrm{MA} / \mathrm{PhD}) ; 3$. submit only one doctoral award application in 
a given academic year. Nominations to the Vanier CGS program do not count towards this limit; 4. not have already received a doctoral-level scholarship or fellowship from CIHR, NSERC or SSHRC.

Level of Study: Postgraduate

Type: Scholarship

Value: C\$21,000 per year

Length of Study: 3 years

Country of Study: Canada

Application Procedure: Refer to the CGS D program description for information on applying to the PGS D program: www.nserc-crsng.gc.ca/Students-Etudiants/PGCS/CGSD-BESCD_eng.asp

Closing Date: 17 October

Additional Information: www.nserc-crsng.gc.ca/StudentsEtudiants/PG-CS/BellandPostgrad-BelletSuperieures_eng.asp

\section{For further information contact:}

Email: ambassadors@nserc-crsng.gc.ca

\section{Netherlands Organization for Scientific Research (NWO)}

Lann van Nieuw Oost Indie 300, PO Box 93138, NL-2509

The Hague AC, Netherlands.

Tel: $\quad$ (31) 703440640

Email: nwo@nwo.nl

Website: www.nwo.nl

Contact: F.A.O. Grants Department

The Netherlands Organization for Scientific Research (NWO) is the central Dutch organization in the field of fundamental and strategic scientific research. NWO encompasses all fields of scholarship and consequently plays a key role in the development of science, technology and culture in the Netherlands. NWO is an independent organization that acts as the national research council in the Netherlands. NWO is the largest national sponsor of fundamental scientific research undertaken in the 13 Dutch universities and provides many types of funding for research driven by intellectual curiosity.

\section{Rubicon Programme}

Purpose: To encourage talented researchers at Dutch Universities to dedicate themselves to a career in postdoctoral research
Eligibility: Open to researchers from all scientific disciplines engaged in $\mathrm{PhD}$ research or obtaining a $\mathrm{PhD}$ in the last 12 months

Level of Study: Postdoctorate

Type: Grant

Value: $€ 5,300,000$ a year

Length of Study: Up to 2 years

Application Procedure: A completed application form to be submitted via NOW's electronic submission system Iris

Closing Date: 28 November

Contributor: The Netherlands Ministry of Education, Culture and Science

Additional Information: Total amount for each (current year) Rubicon round is $€ 2,900,000$

\section{For further information contact:}

Tel: (31) 703440565

Email: rubicon@nwo.nl

\section{WOTRO DC Fellowships}

Purpose: To support high-quality $\mathrm{PhD}$ and postdoctorate research projects

Eligibility: Open to project researchers with the appropriate degrees

Level of Study: Doctorate

Value: A contribution to personal living costs and research costs Length of Study: 4 years for $\mathrm{PhD}$ research and 2 years for postdoctorate research

Frequency: Annual

Application Procedure: Applications must be formally submitted by a senior researcher employed at a Dutch research institution, together with a senior researcher from the home country as a co-applicant and as part of the supervising them Contributor: WOTRO

\section{For further information contact:}

Tel: $\quad$ (31) 703440945

Email: dijk@nwo.nl

\section{New England Culninary Institute (NECl)}

Admissions Office, 56 College Street, Montpelier, VT 05602, United States of America.

Tel: $\quad$ (1) 877223324

Website: www.neci.edu 
New England Culinary Institute (NECI) is one of the leading culinary schools in the United States of America. It is located in Vermont, the Green Mountain State. Mr. Fran Voigt and Mr. John Dranow founded NECI in 1980.

\section{Cabot Scholarships}

Purpose: To encourage and support students who are committed to furthering their education and enhancing their careers in the restaurant and food service industry

Eligibility: Open to candidates who are current resident of Vermont, New York, Maine, New Hampshire, Connecticut, Rhode Island or Massachusetts

Level of Study: Professional development

Type: Scholarship

Value: US\$2,000

Length of Study: 1 year

Frequency: Annual

Study Establishment: New England Culinary Institute

Country of Study: United States of America

Application Procedure: Applicant must submit a complete application form to New England Culinary Institute

For further information contact:

Email:1indac@neci.edu

\section{New South Wales Architects Registration Board}

NSW Architects Registration Board, Level 2, 156 Gloucester Street, Sydney, NSW 2000, Australia.

Tel: $\quad$ (61) 292414033

Email: mail@architects.nsw.gov.au

Website: www.architects.nsw.gov.au

Contact: Ms Mae Cruz, Deputy Registrar

\section{Client Service Excellence Award}

Purpose: To encourage excellence in the professional services offered by architects

Eligibility: Open to all architects registered in New South Wales (NSW) who have completed projects in the last 2 years in NSW not exceeding AU\$4 million

Level of Study: Unrestricted

Type: Award

Value: AU $\$ 5,000$
Frequency: Annual

Country of Study: Any country

Application Procedure: For further information about the Client Service Excellence Award contact the Registrar of the NSW Architects Registration Board on (61) 292414033. Check website for further details

Closing Date: 28 September

Contributor: Victorian Architects Registration Board

Additional Information: Architect, architect corporations, and firms should have two nominations from clients

\section{For further information contact:}

Email: awards@rcsa.com.au

\section{New South Wales Ministry of the Arts}

Level 9 St James Centre, 111 Elizabeth Street, PO Box A226, Sydney, NSW 1235, Australia.

Tel:

1800358594 , (61) 282182222

Email: mail@arts.nsw.gov.au

Website: www.arts.nsw.gov.au

New South Wales Ministry of the Arts works closely with the State's 8 major cultural institutions, providing policy advice to Government on their operations.

\section{Western Sydney Artists Fellowship}

Purpose: To encourage artists and students in the field of creative arts

Eligibility: Open to applicants who are residents of Western Sydney or whose practice is located primarily in Western Sydney

Level of Study: Postgraduate

Type: Fellowship

Value: AU\$5,000-25,000

Length of Study: 1 year

Frequency: Annual

Study Establishment: New South Wales, Sydney Western Suburbs

Country of Study: Australia

Closing Date: September

For further information contact:

Email: mail@create.nsw.gov.au 


\section{New York Foundation for the Arts (NYFA)}

20 Jay Street, 7th floor, Brooklyn, NY 11201, United States of America.

Tel: $\quad$ (1) 2123666900

Email:_fellowships@nyfa.org

Website: www.nyfa.org

New York Foundation for the Arts (NYFA), founded in 1971, helps artists turn inspiration into art by giving more money and support to individual artists and arts organizations than any other comparable institution in the United States.

\section{Canadian Women Artists' Award}

Purpose: The Canadian Women Artist's Award is open to emerging or early career artists in New York, New Jersey, and Connecticut. The C $\$ 5,000$ award is designed to provide financial support to an emerging or early career artist working in any discipline, and can be used in any manner the recipient deems necessary to further their artistic goals. It is supported by funding granted to NYFA by the Canadian Women's Club (CWC) of New York as a way to continue its philanthropic work when it disbanded

Eligibility: The Canadian Women Artist's Award is open to women artists who meet the following requirements: Must be a Canadian citizen, and able to provide proof of citizenship with legal documentation upon receipt of the award; Must be between the ages of 21 and 35 before the application deadline; Must be a current resident of New York, New Jersey, or Connecticut; Must apply in only one of the eligible discipline categories; Must be the originators of the work, i.e. choreographers or playwrights; not awarded to interpretative artists such as dancers or actors; Must not be a previous recipient of the Canadian Women Artist's Award; Must not be a NYFA employee, member of the NYFA Board of Trustees or Artists' Advisory Committee, and/or an immediate family member of any of the previous

Level of Study: Unrestricted

Type: Award

Value: $C \$ 5,000$

Frequency: Annual

Country of Study: Any country

Application Procedure: All applicants must apply online at apply.nyfa.org/submit. The application cycle runs through the Spring, opening in March and closing in May

No. of awards offered: 82
Closing Date: May

Funding: Private, Foundation

Contributor: The Canadian Women's Club (CWC) of New York

No. of awards given last year: 1

No. of applicants last year: 82

Additional Information: www.nyfa.org/Content/Show/ Canadian-Women-Artists'-Award

\section{"Made in NY" Women's Film, TV and Theatre Fund}

Purpose: The "Made in NY" Women's Film, TV and Theatre Fund provides grants to encourage and support the creation of film, television, digital, and live theatre content that reflects the voices and perspectives of all who identify as women

Eligibility: In addition to being made by, for, or about all who identify as women, projects are eligible if they feature a strong female perspective; and/or include a female director; and/or include a meaningful female producer credit; and/or include a meaningful female writing credit; and/or include a female protagonist(s). Projects must also meet the "Made in NY" criteria as described in the program guidelines

Level of Study: Unrestricted

Type: A variable number of grants

Value: US\$20,000 - US\$50,000

Frequency: Annual

Country of Study: Any country

Application Procedure: All applications must be submitted online at apply.nyfa.org/submit. Applications open in the summer, and close in the fall

No. of awards offered: 568

Closing Date: October

Funding: Government

Contributor: The City of New York Mayor's Office of Media and Entertainment (MOME)

No. of awards given last year: 60

No. of applicants last year: 568

\section{New York State Council on the Arts/New York Foundation for the Arts Artist Fellowship}

Eligibility: 1. 25 years or older 2. Current residents of New York State and/or one of the Indian Nations located in New York State 3. Must have maintained New York State residency, and/or residency in one of the Indian Nations located therein, for at least the last two consecutive years $(2018$ \& 2019) 4. Cannot be enrolled in a degree-seeking program of any kind 5. Are the originators of the work, i.e. choreographers or playwrights, not interpretive artists such as dancers or actors 6. Did not receive a NYSCA/NYFA Artist Fellowship in any 
discipline in the past five consecutive years: 2015, 2016, 2017, 2018, and 2019 7. Cannot submit any work samples that have been previously awarded a NYSCA/NYFA Artist Fellowship 8. While collaborating artists are eligible to apply, the total number of collaborators cannot exceed three 9. Are not a current NYFA employee or have been in the last 12 months, a member of the NYFA Board of Trustees or Artists' Advisory Committee, immediate family member of any of the aforementioned, or an immediate family member of a 2019-2020 panelist 10. Artists that have been awarded five NYSCA/NYFA Artist Fellowships receive Emeritus status and are no longer eligible for the award

Type: Fellowship

Value: US $\$ 7,000$

Length of Study: Unrestricted

Frequency: Annual

Closing Date: 22 January

Additional Information: www.nyfa.org/content/Show/

Artists'-Fellowships

\section{Rauschenberg Emergency Grants}

Purpose: New York Foundation for the Arts (NYFA) is proud to partner with the Robert Rauschenberg Foundation to administer a new emergency grant program called Rauschenberg Emergency Grants. This marks the first phase of a program that will be in the tradition of Change, Inc., a non-profit foundation established in 1970 by Robert Rauschenberg to assist professional artists of all disciplines in need of emergency medical aid.

Eligibility: Open to visual and media artists and choreographers. If you aren't sure if your artistic discipline fits within these guidelines, please contact emergencyfunds@nyfa.org. 1. Open to artists who are U.S. citizens or permanent residents in the United States, District of Columbia, or U.S. Territories. 2. Applicants must demonstrate current and ongoing activity in artistic discipline/s. 3. Applicants cannot be enrolled in any degree-seeking program

Type: Grant

Value: Up to US $\$ 5,000$

Frequency: Annual

Application Procedure: Apply online: apply.nyfa.org/sub mit/0696520d-f013-454d-8846-8da806d3920a/rauschenbergemergency-grants

Closing Date: June

Additional Information: www.nyfa.org/Content/Show/ Rauschenberg-Emergency-Grants

\section{For further information contact:}

New York Foundation for the Arts, 20 Jay Street, Suite 740, Brooklyn, NY 11201, United States of America.

Email: emergencyfunds@nyfa.org

\section{Recharge Foundation Fellowship for New Surrealist Art}

Purpose: The New York Foundation for the Arts (NYFA) created the Recharge Foundation Fellowship for New Surrealist Art, a US\$5,000 award for painters living in the United States and U.S. Territories who are working in the New Surrealist style, in 2019. The award program is administered by NYFA with funding provided by the Gu Family of the Recharge Foundation.

Type: Grant

Value: US\$7,000

Frequency: Annual

Application Procedure: The JGS Fellowship for Photography is open to New York State photography artists, living and working anywhere in the following regions of New York State: Western New York, Finger Lakes, Southern Tier, Central New York, North Country, Mohawk Valley, Capital District, Hudson Valley, and Long Island. 1. Applicants must work in photography. 2. Applicants can work in traditional and experimental photography or any form in which photography or photographic techniques are pivotal, if not exclusive. 3. Applicants must be a current full-time resident of New York State and have lived full-time in one of the regions listed above for a minimum of 12 months at the time applications close. 4. Applicant must be at least 25 years of age at the time the application closes. 5. Students in bachelor's or master's degree programs of any kind are not eligible to apply. 6. All past recipients of any NYFA grant or Fellowship are eligible to apply. 7. NYFA employees, members of the NYFA Board of Trustees or Artists' Advisory Committee, and/or an immediate family member of any of the above cannot apply. Closing Date: 15 May

Additional Information: www.nyfa.org/Content/Show/TheRecharge-Foundation-Fellowship-for-New-Surrealist-Art

\section{New York University}

\section{Provost's Postdoctoral Fellowship Program}

Purpose: NYU Provost's Postdoctoral Fellowship Program supports promising scholars and educators from diverse backgrounds whose life experience and research background will contribute significantly to academic excellence at NYU

Eligibility: 1. NYU Provost's Postdoctoral Fellowship Program is open to all areas of study represented at the University. Individuals who meet one of the following criteria are eligible to apply. 2. Individuals who have completed their dissertation within the last three years or who will have completed their dissertation by 1 September. 3. Professionals transitioning to academic careers in a field for which the doctorate is not the terminal degree 
Level of Study: Postgraduate

Type: Fellowship

Frequency: Annual

Country of Study: Any country

Application Procedure: Required application materials include: 1 . a curriculum vitae. 2 . a statement of research and goals. 3. a personal statement detailing reasons for applying for the fellowship. 4. mentorship plan developed jointly with the proposed mentor (see below). 5. three letters of recommendation (with one of those letters to come from the proposed mentor at NYU). 6. one of the following: A dissertation abstract (postdoctoral applicants); or a statement of how your professional experience prepares you for a faculty position non- $\mathrm{PhD}$ terminal degree holders; and candidate information form

Closing Date: 15 January

Funding: Private

Additional Information: www.nyu.edu/faculty/facultydiversity-and-inclusion/mentoring-and-professional-develop ment/provosts-postdoctoral-fellowship-program.html

\section{For further information contact:}

383 Lafayette Street, New York, NY 10003, United States of America.

Email: admissions.ops@nyu.edu

\section{New York University Academic and Science}

\section{Rangel Graduate Fellowship Program}

Purpose: The Rangel Graduate Fellowship is a United States Department of State program, administered by Howard University, that seeks to attract and prepare outstanding young people for careers as Foreign Service Officers in the United States Department of State

Eligibility: 1. Applicants must be seeking admission to enter graduate school in the fall for a two-year program at a United States university in an area of relevance to the Foreign Service. They can be in their senior year of their undergraduate studies, graduating by June, or they can be college graduates. 2. Applicants must have a cumulative grade point average of 3.2 or higher on a 4.0 scale at the time of application. 3. Applicants must be United States citizen

Level of Study: Postgraduate

Type: Fellowship

Value: Up to US $\$ 37,500$ annually toward tuition, fees and living expense

Frequency: Annual

Country of Study: United States of America
Application Procedure: The Rangel Program expects to award 30 fellowships each November for cohort. A panel of individuals with experience in the United States Foreign Service and academia makes selections for the Rangel Program. A candidate's community, academic, extracurricular, and leadership activities will be considered during the selection process. For further details, check the following link. rangelprogram.org/graduate-fellowship-programapplication/

Closing Date: 17 September

Funding: Private

Additional Information: www.unigo.com/scholarships/ minority/asian-scholarships/rangel-graduate-fellowship/ 1004264

\section{For further information contact:}

2218 6th Street NW, Washington, DC 20059, United States of America.

Tel: $\quad$ (1) 8776330002

Email: rangelprogram@howard.edu

\section{New Zealand Aid Programme}

195 Lambton Quay, Private Bag 18 901, Wellington 6160, New Zealand.

Tel: $\quad$ (64) 44398000

Contact: Ministry of Foreign Affairs and Trade

The purpose of New Zealand's aid is to develop shared prosperity and stability in the Pacific and beyond, drawing on the best of New Zealand's knowledge and skills. We support sustainable development in developing countries to reduce poverty and contribute to a more secure, equitable and prosperous world.

\section{New Zealand Pacific Scholarships}

Purpose: A particular focus of NZPS is to increase the number of young pacific people studying in New Zealand and to build a new generation of Pacific leadership with strong links to New Zealand

Type: Scholarship

Country of Study: Any country

Application Procedure: For application procedure, please refer website www.mfat.govt.nz/en/aid-and-development/ scholarships/how-to-apply/

Closing Date: 28 March 
Additional Information: scholarship-positions.com/newzealand-pacific-scholarships-for-pacific-countries/2011/06/11/

\section{For further information contact:}

Email: studentinfo@auckland.ac.nz

\section{Newberry Library}

60 West Walton Street, Chicago, IL 60610-3380, United States of America.

Tel: $\quad$ (1) 3129439090

Email: research@newberry.org

Website: www.newberry.org

Contact: Research and Education

The Newberry Library, open to the public without charge, is an independent research library and educational institution dedicated to the expansion and dissemination of knowledge in the humanities. With a broad range of books and manuscripts relating to the civilizations of Western Europe and the Americas, the Library's mission is to acquire and preserve research collections of such material, and to provide for and promote their effective use by a diverse community of users.

\section{Associated Colleges of the Midwest/the Great Lakes Colleges Association Faculty Fellowships}

Purpose: This fellowship supports faculty from the colleges of the Associated Colleges of the Midwest and the Great Lakes Colleges Association, Inc

Eligibility: Applicants can come from any of the colleges in ACM or GLCA, from any discipline

Type: Fellowship

Value: Fellows teach a small group of select undergraduate students in an advanced research seminar

Application Procedure: Potential applicants should contact Joan Gillespie at the ACM

Closing Date: 15 March

Additional Information: For more information, visit the Associated Colleges of the Midwest's call for proposals at www.acm.edu/programs/14/newberry/index.html

\section{For further information contact:}

Tel: $\quad$ (1) 3122635000

Email: jgillespie@acm.edu

\section{Long-Term Fellowships}

Purpose: Long-Term Fellowships are intended to support individual scholarly research and promote serious intellectual exchange through active participation in the Newberry's scholarly activities, including Fellows' Seminars and Weekly Colloquium.

Eligibility: For more information on eligibility, guidelines, and the application process, please visit: www.newberry.org/ how-apply

Level of Study: Postgraduate

Type: Fellowships

Value: US $\$ 4,200$ per month

Length of Study: 4 to 9 months

Frequency: Annual

Study Establishment: The Newberry Library

Country of Study: United States of America

Application Procedure: For more information on eligibility, guidelines, and the application process, please visit: www. newberry.org/how-apply

Closing Date: 1 November

Funding: Private

Additional Information: If you have any additional questions about the Newberry's Fellowship Program, please email research@newberry.org.www.newberry.org/long-term-fellow ships

\section{Rudolph Ganz Fellowship}

Purpose: The Rudolph Ganz Fellowship is a new opportunity at the Newberry Library. The fellowship is intended to support research using the Rudolph Ganz Papers and other late nineteenth- and early twentieth-century materials related to Chicago music in that period. The Rudolph Ganz Papers include the musical compositions of this world-renowned concert pianist, composer, conductor, and educator, as well as articles, speeches, lectures and essays by him, and two recordings. Also in the collection is correspondence to and from prominent musical figures, family correspondence, clippings, photographs, programs, and some artifacts

Eligibility: Applicants must demonstrate a specific need for the Newberry's collection. For additional information about eligibility requirements and application guidelines, please check the website: www.newberry.org/fellowships

Type: Scholarship

Value: Short-Term Fellowships are generally awarded for one continuous month in residence at the Newberry, with stipends of US\$2,500 per month

Country of Study: United States of America

Closing Date: 15 December

Additional Information: networks.h-net.org/node/73374/ announcements/85457/rudolph-ganz-fellowship 


\section{Weiss/Brown Publication Subvention Award}

Subjects: Music, theater, cultural studies, or French or Italian literature

Purpose: To subsidize the publication of scholarly book or books on European civilization before 1700 in the areas of music, theater, cultural studies, or French or Italian literature Type: Grant

Value: Up to US $\$ 8,000$

Length of Study: Doctorate, Postdoctorate

Frequency: Annual

Country of Study: United States of America

Application Procedure: For more information, please see www.newberry.org/how-apply

Funding: The Newberry Library

Additional Information: www.newberry.org/publicationsubvention

\section{Newcastle University}

Manager, Student Financial Support, Newcastle University, King's Gate, Newcastle upon Tyne NE1 7RU, United Kingdom.

\section{Tel: $\quad$ (44) 1912083333}

Email: scholarship.applications@ncl.ac.uk

Website: www.ncl.ac.uk

Contact: Mrs Rencesova Irena, Student Financial Support Officer

The Newcastle University, established in Newcastle in 1834, is one of the United Kingdom's leading universities and is known for its quality of teaching, outstanding research, and works with the regional and local communities, business and industry.

\section{Advancing Women in Leadership Scholarship (MBA)}

Purpose: We're committed to supporting innovative business women who aspire to higher levels of influence and professional development. Successful candidates will demonstrate a strong career trajectory, academic excellence and a wealth of professional experience

Eligibility: To be eligible for this partial-fee scholarship you must meet the following criteria: 1 . complete the scholarship application form including submitting an essay of no more than 1,500 words in response to the question listed. Submissions need to be in English. 2. hold a conditional or unconditional offer of admission to the Full-time MBA programme entry. 3. have substantive managerial experience (normally 6 years or more, minimum 3 years). 4. preferably hold the equivalent of a United Kingdom 2:1 honours degree (however, applicants who do not meet this requirement but can demonstrate relevant work experience above the minimum plus significant career progression may also be considered). 4. perform well at interview across all competency areas. 5. hold an English language qualification of IELTS 6.5 or its equivalent with no subskill below 6.0 (if your first language is not English)

Level of Study: Postgraduate

Type: Scholarship

Value: A full fee award of $£ 22,800$, payable towards the cost of tuition fees

Frequency: Annual

Study Establishment: Newcastle University Business School

Country of Study: Any country

Application Procedure: Applications and essays will be reviewed by a panel of judges. Candidates need to complete the online application form. forms.ncl.ac.uk/view.php? id $=2981403$

Closing Date: 5 April

Funding: Private

Contributor: Newcastle University Business School

Additional Information: www.scholarshubafrica.com/ 34923/advancing-women-leadership-scholarship-mba-new castle-university-uk/

\section{For further information contact:}

Tel: (44) 1912081589

Email: mba@ncl.ac.uk

\section{British Marshall Scholarships}

Purpose: If you are an American graduate, and aged under 26 , you may be eligible to apply for one of 40 competitive awards. The British Marshall Scholarships will finance two years of postgraduate and occasionally, undergraduate study in the United Kingdom

Eligibility: The scholarships cover: 1. fares to and from the United States. 2. university tuition fees. 3. cost of living expenses. 4. book, thesis, research and daily travel allowances and where applicable, a contribution towards the support of a dependent spouse

Level of Study: Postgraduate

Type: Scholarship

Value: Varies

Length of Study: Two years

Frequency: Annual 
Country of Study: Any country

Application Procedure: For further information about the scholarship and details on eligibility and applications, contact the Marshall Aid Commemoration Commission. www. marshallscholarship.org/

Funding: Private

Contributor: The Marshall Aid Commemoration Commission Additional Information: www.marshallscholarship.org/ apply/criteria-and-who-is-eligible

\section{For further information contact:}

Tel: (44) 1912086000

Email: apps@marshallscholarship.org

\section{European Excellence Scholarship (MBA)}

Purpose: Our MBA provides an inclusive, diverse and collaborative learning community that educates and develops our students to be creative, innovative, enterprising and global in their outlook

Eligibility: To be eligible for this full-fee scholarship you must meet the following criteria: 1. completed the scholarship application form including submitting an essay of no more than 1,500 words in response to the question listed. Submissions need to be in English. 2. hold a conditional or unconditional offer of admission to the Full-time MBA programme entry. 3. have substantive managerial experience (minimum 3 years prior to starting the MBA) preferably hold the equivalent of a United Kingdom 2:1 honours degree (however, applicants who do not meet this requirement but can demonstrate relevant work experience above the minimum plus significant career progression may also be considered). 4. perform well at interview across all competency areas. 5. hold an English language qualification of IELTS 6.5 or its equivalent with no subskill below 6.0 (if your first language is not English). 6. be assessed as an European Union student for fee paying purposes

Level of Study: Postgraduate

Type: Scholarship

Frequency: Annual

Country of Study: Any country

Application Procedure: Applications and essays will be reviewed by a panel of judges. Candidates need to complete the online application form

Closing Date: 5 April

Funding: Private

Additional Information: www.ncl.ac.uk/business-school/ courses/scholarships/mba/

\section{For further information contact:}

Tel: (44) 1912081589

Email: mba@ncl.ac.uk

\section{Humanities and Social Sciences Postgraduate Scholarships}

Purpose: The Faculty of Humanities and Social Sciences at Newcastle University is pleased to offer Humanities and Social Sciences Postgraduate scholarships to assist non-UK European Union nationals to study a postgraduate Master's degree.

Eligibility: To be considered for awards applicants must: 1. hold the equivalent of a first class UK honours degree 2. have an offer for an eligible, full time, taught postgraduate degree programme within the Faculty of Humanities and Social Sciences. Applicants applying to Newcastle University Business School are not eligible for these awards 3. must be non UK European Union nationals and must be classed as EU for fee paying purposes. 4. Eligible candidates will be assessed as part of their academic application.

Level of Study: Postgraduate

Type: Scholarship

Value: $£ 2,000$ tuition fee awards.

Frequency: Annual

Country of Study: United Kingdom

Application Procedure: Eligible candidates will automatically be considered for a Humanities and Social Sciences Postgraduate Scholarship as part of their academic course application.

Closing Date: September

Funding: Private

Additional Information: www.ncl.ac.uk//postgraduate/ funding/sources/ukeustudents/hsspgs $20 . h$ tml

\section{Indonesia Endowment Fund for Education (LPDP)}

Purpose: The Indonesia Endowment Fund (LPDP) provides funding for high achieving Indonesian students undertaking Master's or PhD study. It forms part of the Indonesian government's aim to nurture young talented individuals, enabling them to become future leaders

Eligibility: For detailed information about the eligiblity, check the website

Level of Study: Postgraduate

Type: Funding support

Value: The scholarship covers tuition fees and living expenses

Frequency: Annual

Study Establishment: Ministry of Finance and Minister of Research, Technology and Higher Education

Country of Study: Any country

Application Procedure: For detailed information grants, check the following link, www.lpdp.kemenkeu.go.id

Closing Date: October

Funding: Private 
Contributor: Lembaga Pengelolaan Dana Pendidikan (LPDP)

Additional Information: www.ncl.ac.uk/postgraduate/ funding/sources/internationalnoneustudents/lpdp19.html

\section{For further information contact:}

Email: cso.lpdp@kemenkeu.go.id

\section{International Family Discounts (IFD)}

Purpose: We offer discounts to encourage relatives of our current international students, and past international graduates, to pursue their studies at Newcastle University

Eligibility: 1. This discount is only available to students studying at the Newcastle city campus. 2. The University offers partial discounts to close relatives (husband, wife, brother, sister, mother, father, son or daughter) of students and graduates, who have been assessed as International for fees purposes, and who wish to pursue their studies at Newcastle University in currently studying here. 3. Students may only apply for a discount if they are registered as a student at the University or after they have been offered a place to study on their chosen degree programme, and have been assessed as International for fees purposes

Level of Study: Postgraduate

Type: Funding support

Value: $10 \%$ of the tuition fee per year

Frequency: Annual

Country of Study: Any country

Application Procedure: Please complete the online International Family Discount application form in accordance with the IFD regulations. Further updates on regulatiobns and applications are available at: forms.ncl.ac.uk/view.php? $\mathrm{id}=12481$

Funding: Private

Additional Information: www.ncl.ac.uk/postgraduate/ funding/sources/internationalnoneustudents/ifd.html

For further information contact:

Tel: (44) 1912085537

\section{Master of Arts (Taught Masters) Scholarships in the School of Modern Languages}

Purpose: The School of Modern Languages is offering competitive scholarships to outstanding applicants for the following programmes: MA programmes in Translating and Interpreting (Chinese) MA in Professional Translating for European Languages (French, German, Italian, Spanish) MA Film: Theory and Practice
Eligibility: Home, European Union and International Students are eligible to apply

Level of Study: Postgraduate

Type: Scholarship

Value: $£ 5,000$

Frequency: Annual

Country of Study: Any country

Application Procedure: In order to apply for the scholarship, check the website. www.ncl.ac.uk/sml/study/funding/ \#currentopportunities

Closing Date: 7 June

Funding: Private

Contributor: SML Postgraduate Officer

\section{For further information contact:}

Tel: (44) 1912085867

Email: modlang.pgadmin@ncl.ac.uk

\section{Master of Arts in Art Museum and Gallery Studies Scholarship}

Purpose: The Art Museum and Gallery Studies MA provides students with the opportunity to develop skills as a curator or gallery educator in the fields of both historical and contemporary art

Eligibility: The studentships are open to United Kingdom, European Union and international applicants who hold, or expect to achieve a minimum of a 2.1 Honours degree (or international equivalent) in fine art or an art related subject. We welcome applications from all sections of the community regardless of race, ethnicity, gender or sexuality, and wish to encourage applications from traditionally underrepresented groups in United Kingdom higher education. International students If your first language is not English you must also meet our English language requirements

Level of Study: Professional development

Type: Scholarship

Value: $£ 3,000$

Frequency: Annual

Country of Study: Any country

Application Procedure: You must apply through the University's online postgraduate application system. To do this please 'Create a new account'. All relevant fields should be completed, but fields marked with a red asterisk must be completed. The following information will help us to process your application. You will need to: 1 . insert the programme code $4138 \mathrm{~F}$ in the programme of study section. 2. select 'MA Art Museum and Gallery Studies (full time)' as the programme of study. 3. insert the studentship code SAC025 in the studentship/partnership reference field. 4 . attach a personal statement of no more than 500 words outlining. i. your preparedness to 
undertake the Art Museum and Gallery Studies MA. ii. your aspirations for a career in the art museum and gallery sector Closing Date: 30 April

Funding: Private

Additional Information: www.ncl.ac.uk/postgraduate/ courses/degrees/art-museum-gallery-studies-ma-pgdip/\#profile

\section{For further information contact:}

Email: gerard.corsane@ncl.ac.uk

\section{Master of Business Administration Business Excellence Scholarships}

Purpose: The scholarship program will be awarded to a high caliber candidate with at least 5 years of work experience who can demonstrate achievement and impact in a business environment. Our MBA Business Excellence Scholarships will reward MBA candidates who are results orientated, customer focused, and can demonstrate emerging leadership qualities Eligibility: To be eligible for this partial-fee scholarship you must meet the following criteria: 1. can demonstrate (through application and at interview) substantive managerial experience and good leadership potential for the future. 2. hold a conditional or unconditional offer of admission to the Full-time MBA programme entry. 3. have substantive managerial experience (normally 4 years or more, minimum 3 years) preferably hold the equivalent of a United Kingdom 2:1 honours degree (however, applicants who do not meet this requirement but can demonstrate relevant work experience above the minimum plus significant career progression may also be considered). Perform well at interview across all competency areas hold an English language qualification of IELTS 6.5 or its equivalent with no subskill below 6.0 (if your first language is not English)

Level of Study: Postgraduate

Type: Scholarship

Frequency: Annual

Study Establishment: Newcastle University Business School Country of Study: Any country

Application Procedure: No application required. All candidates will be assessed at the point of interview for this Scholarship

Closing Date: 5 April

Funding: Private

Additional Information: studyabroad.shiksha.com/scholar ships/newcastle-university-mba-business-excellence-scholar ships

\section{For further information contact:}

Tel: $\quad$ (44) 1912081589

Email: mba@ncl.ac.uk

\section{Newcastle University - English Language Excellence Scholarships (Business School Masters)}

Purpose: Newcastle University Business School offers a number of partial scholarship awards to outstanding and high-quality Masters students each year to assist them to study for a Masters degree

Eligibility: You will be considered for an English Language Excellence Scholarship if you hold an unconditional offer for one of the following Masters courses: 1. Arts, Business and Creativity MA. 2. Innovation, Creativity and Entrepreneurship MSc. 3. Global Human Resource Management MSc. 4. International Economics and Finance MSc. 5. Banking and Finance MSc. 6. Finance MSc. 7. Quantitative Finance and Risk Management MSc. 8. International Business Management MSc. 9. International Marketing MSc. 10. Operations, Logistics and Supply Chain Management MSc. 11. Accounting, Finance and Strategic Investment MSc. 12. International Financial Analysis MSc. 13. E-Business MSc. 14. E-Business (Information Systems) MSc. 15. E-Business (E-Marketing) MSc

Level of Study: Postgraduate

Type: Scholarship

Value: Partial awards of $£ 5,000$ towards the cost of tuition fees Frequency: Annual

Country of Study: Any country

Application Procedure: Regulations and application details are available on the below link, www.ncl.ac.uk/media/ wwwnclacuk/postgraduate/funding/files/English\%20Language\% 20Excellence\%20Scholarships\%20Regulations\%202019\% 20Entry.pdf

Funding: Private

\section{For further information contact:}

Email: nubs@ncl.ac.uk

\section{Newcastle University - United States of America Athlete Scholarship}

Purpose: Newcastle University offers partial scholarship awards to encourage United States of America athletes to undertake Master's level study

Eligibility: Applicants should ideally have NCAA D1- D3 playing experience in one of the following sports: Basketball, Lacrosse, Volleyball, Tennis, Golf, Women's Soccer, Waterpolo. They must also be: 1. registered at Newcastle University for the academic year. 2. registered for one of the following eligible courses Masters - MA; MBA; MClinRes; MEd; MMedEd; LLM; LLM (by research); MLitt; MMus; MPH; MRes; MSc. 3. defined as international for fee purposes. 4. resident in the United States of America. 5. registered to study at Newcastle University city centre campus 
Level of Study: Graduate

Type: Scholarship

Value: $40 \%$ fee reduction, $£ 5,000$ - $£ 8,000$ payable towards the first year of tuition fees and a comprehensive support package (see Overview for further details)

Frequency: Annual

Country of Study: Any country

Application Procedure: Complete the application form using the following link. www.ncl.ac.uk/nclsport/perfor mance/scholarships/application.htm

Closing Date: 31 July

Funding: Private

Contributor: Newcastle University Performance Sport Team

\section{For further information contact:}

Tel: (44) 1912085230

Email: performance.sport@newcastle.ac.uk

\section{Newcastle University - Vice-Chancellor's Excellence Scholarships - Postgraduate}

Purpose: Newcastle University is pleased to offer 40 ViceChancellor's Excellence Scholarships (VCES) for outstanding international applicants who apply to commence full-time Master's studies. There are 39 50\% tuition fee scholarships and 2 100\% tuition fee scholarship

Eligibility: To be considered for the 50\% scholarships applicants must: be a national of one of the following countries: Algeria, Argentina, Brazil, Canada, Chile, China, Colombia, Ecuador, Egypt, India, Indonesia, Jordan, Lebanon, Malaysia, Mexico, Morocco, Peru, Thailand, Turkey, United States of America, Venezuela be assessed as international for fee purposes hold an offer for an eligible Master's degree programme at the University's Newcastle city centre campus for the academic year already have or expect to receive the equivalent of an upper second class United Kingdom honours degree or above

Level of Study: Postgraduate

Type: Scholarship

Frequency: Annual

Study Establishment: Newcastle University

Country of Study: Any country

Application Procedure: Online application form is available on the below web link path. app.geckoform.com/public/\#/ modern/FOEU01c3zJ6qAVgh

Closing Date: 28 June

Funding: Private

Contributor: Newcastle University

Additional Information: www.ncl.ac.uk/undergraduate/ fees-funding/scholarships-bursaries/vc-excellence/

\section{Newcastle University International Postgraduate Scholarship (NUIPS)}

Purpose: To provide a partial scholarship for international students

Eligibility: Candidates for scholarships must already have been offered a place to study at Newcastle University. See webpages: www.ncl.ac.uk/postgraduate/funding/search/list/ nuips

Level of Study: Postgraduate

Type: Partial scholarship

Value: $£ 2,000$ per year

Length of Study: 1st year of study only

Frequency: Annual

Study Establishment: Newcastle University

Country of Study: United Kingdom

Application Procedure: All eligible applicants who are offered a place to study at Newcastle University are invited to apply for one of these scholarships. Applicants must check the website for details or contact the Student Financial Support Team

No. of awards offered: 800

Closing Date: 27 May

Contributor: Newcastle University

No. of awards given last year: 100

No. of applicants last year: 800

Additional Information: www.scholarshipsads.com/ newcastle-university-international-postgraduate-scholarshipnuips-uk/

\section{For further information contact:}

Email: international-scholarships@ncl.ac.uk

\section{Newcastle University Overseas Research Scholarship (NUORS)}

Purpose: Newcastle University is committed to offering support to the very best international students hoping to pursue a programme of research. We are pleased to offer a small number of University funded NUORS awards for outstanding international students who apply to commence $\mathrm{PhD}$ studies in any subject

Eligibility: 1. You could be eligible to apply for a NUORS award if. 2. you have been offered a place on a $\mathrm{PhD}$ research programme. 3. you have been assessed as international/overseas for fees purposes, and are wholly or partially selffinancing. 4. you intend to register to start your studies during the academic year

Level of Study: Graduate

Type: Scholarship 
Value: This award covers the difference between home and overseas fee rates (value approximately $£ 11,490$ to $£ 17,700$ per annum)

Frequency: Annual

Country of Study: Any country

Application Procedure: You must have already applied for and been offered a place to study at Newcastle University before you apply for a NUORS award. Please complete the online NUORS application form and in accordance with the NUORS regulations. You will also be required to provide details of an academic referee; the University will then contact your referee directly. Further details can be found in the NUORS Regulations 19-20? Please read these thoroughly before applying. forms.ncl.ac.uk/view.php?id=2526301

Closing Date: 26 April

Funding: Private

Additional Information: www.ncl.ac.uk/postgraduate/ funding/sources/internationalnoneustudents/nuors.html

\section{For further information contact:}

Tel: (44) $1912085537 / 8107$

\section{Newcastle University Scholarship - Thailand - GREAT}

Purpose: This year, in partnership with the British Council and the GREAT Britain Campaign, Newcastle University is offering scholarships to students in Thailand applying for postgraduate taught courses listed below. This scholarship scheme is part of the "GREAT Scholarships - East Asia" campaign, which has been launched by the British Council together with 28 United Kingdom universities to support more students in East Asia to get access to the excellent United Kingdom higher education opportunities

Eligibility: To be considered for awards applicants must: 1. Must be passport holders of Thailand. 2. be assessed as international for fee purposes. 3. hold an offer for an eligible Master's degree programme listed below. 4. MSc Sustainable Chemical Engineering. 5. MSc REFLEX (Renewable Energy Flexible Training Programme)

Level of Study: Postgraduate

Type: Scholarship

Value: Full tuition fees

Frequency: Annual

Study Establishment: Newcastle University

Country of Study: Any country

Application Procedure: Applications must be submitted using the application form. Other applications will not be accepted. Application link is available below: app. geckoform.com/public/\#/modern/FOEU01c3zJ6qAVgh

Closing Date: 30 April

Funding: Private
Contributor: British Council and Newcastle University Additional Information: app.geckoform.com/public/\#/mod ern/FOEU01c3zJ6qAVgh www.wemakescholars.com/schol arship/newcastle-university-great-scholarships-thailand

\section{For further information contact:}

Email: scholarship.applications@newcastle.ac.uk

\section{Newcastle Vice-Chancellor's Global Scholarships - Postgraduate}

Purpose: Newcastle University is pleased to offer 5 ViceChancellor's Global Scholarships (VCGS) for outstanding international applicants who apply to commence full-time Master's studies

Eligibility: To be considered for the Vice-Chancellor's Global Scholarships applicants must: 1. be assessed as international for fee purposes. 2. hold an offer for an eligible Master's degree programme at the University's Newcastle city centre campus for the academic year. 3 . already have or expect to receive the equivalent of an upper second class United Kingdom honours degree or above. 4. Applicants from the following countries are not eligible to apply for VCGS awards as the University offers specific schemes for these countries: Algeria, Argentina, Brazil, Canada, Chile, China, Colombia, Ecuador, Egypt, Ghana, India, Indonesia, Jordan, Kenya, Lebanon, Malaysia, Mexico, Morocco, Nigeria, Peru, Thailand, Turkey, United States of America, Uganda, Venezuela, Vietnam. 5. A scheme for postgraduate Master's applicants from Ghana, Kenya, Nigeria and Uganda will be launched in February

Level of Study: Postgraduate

Type: Scholarship

Frequency: Annual

Country of Study: Any country

Application Procedure: For further information about application process, refer the following link. www.ncl.ac.uk/ media/wwwnclacuk/postgraduate/funding/files/VCGS\%20post graduate\%20regulations\%20(2019).pdf

Closing Date: 28 June

Funding: Private

\section{Postgraduate Masters Scholarships in the School of Geography, Politics and Sociology}

Purpose: The scholarships are open to United Kingdom, European Union and international applicants who: Hold an offer of admission on one of the eligible programmes Hold, or expect to achieve, at least a 2.1 honours degree (or international equivalent), in a related discipline 
Eligibility: The scholarships are open to United Kingdom, European Union and international applicants who: 1. Hold an offer of admission on one of the eligible programmes. 2. Hold, or expect to achieve, at least a 2.1 honours degree (or international equivalent), in a related discipline

Level of Study: Postgraduate

Type: Scholarship

Value: $£ 7,410$

Frequency: Annual

Country of Study: Any country

Closing Date: 7 June

Funding: Private

Additional Information: www.ncl.ac.uk/gps/about/funding/ schoolfunding/\#phdscholarships

\section{For further information contact:}

Email: gps.pgr@ncl.ac.uk

\section{Postgraduate Master's Loan Scheme (Students from United Kingdom and non-United Kingdom European Union Countries)}

Purpose: Student loans for full-time, part-time and distance learning Masters degrees in all subjects (taught or research) Eligibility: 1. Taught and research Master's courses in all disciplines (online and campus-based) will normally be eligible, e.g. MA, MSc, MRes, MEd, MBA, LLM, MLitt, MFA. 2. You can receive a loan for an MPhil. However, this programme must lead to a standalone. Master's degree and not be part of a longer $\mathrm{PhD}$ programme. 3. You will not be entitled to receive the Postgraduate Loan if you are eligible to receive healthcare funding from any of the following organisations. i. National Health Service (NHS). ii. Department of Health (DOH). iii. Student Awards Agency Scotland (SAAS). iv. Doctoral degrees (eg PhD, EngD, Integrated PhDs), PG Certificates, PG Diplomas, PGCE's and Master's courses that are currently funded by the undergraduate support system, eg Master of Architecture (MArch), will not be eligible for the Loan. 4. You will not be eligible for the Postgraduate Loan if you are studying towards top-up credits to a gain a Master's qualification after studying a PG Certificate or PG Diploma

Level of Study: Postgraduate

Type: Award

Value: $£ 10,906$

Frequency: Annual

Country of Study: Any country

Application Procedure: The application cycle is still open. The quickest way to apply is online. www.gov.uk/mastersloan/apply

Funding: Private

Additional Information: www.ncl.ac.uk/postgraduate/ funding/sources/ukeustudents/mastersloan.html

\section{For further information contact:}

Email:1tds@ncl.ac.uk

\section{Postgraduate Opportunity Scholarships}

Purpose: The scholarships are available as part of Newcastle University's Postgraduate Support Scheme for Master's students. They have been designed to enable students from under-represented groups to progress to higher level study Eligibility: Postgraduate Opportunity Scholarships are available only to students applying to Newcastle University who meet the following criteria: have been offered a place to study full time for one year or a maximum of two years part time on one of the University's eligible taught or research Master's courses commencing in September. are United Kingdom students progressing from undergraduate courses for which they were charged the higher tuition fee applying and falling into the following categories: 1. a student living in United Kingdom when they entered undergraduate study at any United Kingdom institution. 2. a student living in Scotland when they entered undergraduate study at any English, Northern Irish or Welsh institution. 3. a student living in Northern Ireland when they entered undergraduate study at any English, Scottish or Welsh institution

Level of Study: Postgraduate

Type: Scholarship

Frequency: Annual

Country of Study: Any country

Application Procedure: To apply for the Postgraduate Opportunity Scholarship, please complete the online application form. Check the following link. app.geckoform.com/ public/\#/modern/FOEU01c3RUfcdPr6\%20

\section{Closing Date: 28 June}

Funding: Private

Additional Information: In order to be considered for a Postgraduate Opportunity Scholarship, you must have already applied to the University for an eligible taught or research Master's course and received an offer of a place by this date www.ncl.ac.uk/postgraduate/funding/sources/ ukeustudents/pos20.html

\section{For further information contact:}

Email: uk.postgraduate-scholarships@ncl.ac.uk

\section{Regional Impact Scholarship (MBA)}

Purpose: To support aspiring and established leaders from the region to continue their professional development. The Regional Impact Scholarship is aimed at MBA candidates who can demonstrate their potential to the economy and society of the North East of United Kingdom 
Eligibility: To be eligible for this full-fee scholarship you must meet the following criteria: 1. completed the scholarship application form including submitting an essay of no more than 1,500 words in response to the question listed. Submissions need to be in English. 2. hold a conditional or unconditional offer of admission to the Full-time MBA programme of current year entry. 3. have substantive managerial experience (minimum 3 years prior to starting the MBA). 4. preferably hold the equivalent of a United Kingdom 2:1 honours degree (however, applicants who do not meet this requirement but can demonstrate relevant work experience above the minimum plus significant career progression may also be considered). 5. perform well at interview across all competency areas hold an English language qualification of IELTS 6.5 or its equivalent with no subskill below 6.0 (if your first language is not English)

Level of Study: Postgraduate

Type: Scholarship

Value: A full fee award of $£ 22,800$, payable towards the cost of tuition fees

Frequency: Annual

Country of Study: United Kingdom

Application Procedure: Applications and essays will be reviewed by a panel of judges. Candidates need to complete the online application form. forms.ncl.ac.uk/view.php?id=2981068

Closing Date: 5 April

Funding: Private

Additional Information: www.ncl.ac.uk/business-school/ courses/scholarships/mba/

\section{For further information contact:}

Tel: $\quad$ (44) 1912081589

Email: mba@ncl.ac.uk

\section{Newcastle University in the United Kingdom}

Newcastle upon Tyne, Tyne and Wear NE1 7RU, United Kingdom.

Tel: $\quad$ (44) 1912086000

Contact: Newcastle University

Newcastle University officially, the University of Newcastle

\section{Fully-Funded Postgraduate Scholarships at Newcastle University in the United Kingdom}

Purpose: Students need a good level of English language to study at Newcastle University. English will be the main language you use socially and for study. If English is not their first language they will need to provide a recognised English language test or qualification

Eligibility: Citizens of China, United States of America, Canada, India, Indonesia, Malaysia, Thailand, Singapore, Jordan, Lebanon, Egypt, Turkey, Algeria, Morocco, India, Nigeria, Ghana, Kenya and Uganda are eligible to apply

Type: Postgraduate scholarships

Value: $50 \%$ or $100 \%$ of tuition fees

Study Establishment: Scholarships are awarded to study the subjects offered by the university

Country of Study: United Kingdom

Application Procedure: International preparation courses and graduate diplomas have a different application method. Students apply online through partner INTO. Applications must be submitted using the online application form

Closing Date: 29 June

Additional Information: For more details please browse the website scholarship-positions.com/fully-funded-postgraduatescholarships-newcastle-university-uk/2017/11/14/

\section{For further information contact:}

Email: scholarship.applications@ncl.ac.uk

\section{Newcomen Society of the United States}

211 Welsh Pool Road, Suite 240, Exton, PA 19341, United States of America.

Tel: $\quad$ (1) 6103636600

Email:_mstoner@newcomen.org

Website: www.newcomen.org

Contact: Ms Marcy J. Stoner, Executive Assistant

The Newcomen Society of the United States is a non-profit business educational foundation that studies and supports outstanding achievement in American business.

\section{Harvard/Newcomen Postdoctoral Award}

Purpose: To improve the scholar's professional acquaintance with business and economic history, to increase his or her skills as they relate to this field, and to enable him or her to engage in research that will benefit from the resources of the Harvard Business School and the Boston scholarly community

Eligibility: Open to Scholars who have received a $\mathrm{PhD}$ in history, economics or a related discipline within the past 
10 years, and who would not otherwise be able to attend Harvard Business School

Level of Study: Postdoctorate

Type: Fellowship

Value: US $\$ 46,000$

Length of Study: 1 year

Frequency: Annual

Study Establishment: Harvard Business School in Cambridge, Massachusetts

Country of Study: United States of America

Application Procedure: Applicants must contact Harvard University for further details

Closing Date: 15 March

\section{For further information contact:}

Straus Professor of Business History, Harvard University, Graduate School of Business Administration, Soldiers Field Road, Boston, MA 02163, United States of America.

Tel: $\quad$ (1) 6174956354

Email: tmccraw@hbs.edu

\section{North Atlantic Treaty Organization (NATO)}

Public Diplomacy Division, Office $\mathrm{Nb}$ 106, Boulevard Leopold III, B-1110 Brussels, Belgium.

Tel: $\quad$ (32) 27074111

Email: natodoc@hq.nato.int

Website: www.nato.int

Contact: Academic Affairs Officer

The North Atlantic Treaty was signed in Washington on 1 April, 1949, creating an alliance of 12 independent nations committed to each other's defence. Four more European nations later acceded to the Treaty between 1952 and 1982. On 12 March, 1999, the Czech Republic, Hungary and Poland were welcomed into the Alliance, which now numbers 19 members.

\section{Manfred Wörner Fellowship}

Purpose: To honour the memory of the late Secretary General by focusing attention on his leadership in the transformation of the alliance, including efforts at extending NATO's relations with CEE countries and promoting the principles and image of the Transatlantic partnership
Eligibility: Open to applicants who are citizens of the EAPC countries with proven experience to carry out an important scholarly endeavour within the time limit of the Fellowship

Level of Study: Professional development

Type: Fellowship

Value: $€ 5,000$ (including all travel costs)

Frequency: Annual

Country of Study: Any country

Application Procedure: Application forms can be downloaded from the NATO website

Closing Date: 25 January

Funding: Government

\section{For further information contact:}

Fax: (32) 27075457

Email: academics@hq.nato.int

\section{North Central College}

Graduate Programs MBA Program, 30 North Brainard Street PO Box 3065, Naperville, IL 60566-7065, United States of America.

Tel: $\quad$ (1) 6306375840

Email: grad@noctrl.edu

Website: www.noctrl.edu

Contact: MBA Admissions Officer

North Central College is a private, four year co-educational college located in Naperville, just 30 miles west of Chicago, Illinois. North Central offers over 50 undergraduate majors and six master's programmes.

\section{North Central Association for Counselor Education and Supervision Research Grant Awards}

Purpose: The call for proposals is to fund studies that increase understanding of the counselor education profession (including research, teaching, supervision, leadership and advocacy). Research grant awards will be presented at the business meeting at the NCACES

Eligibility: Proposed topic is within the scope of this Research Award program. Need for the proposed topic is clearly outlined through review of the research. Objectives are clear and attainable in the proposed study. Methodology proposed is appropriate for the research questions. Outcomes are consistent with objectives and method. Research proposed 
adheres to ACA/ACES ethical standards for research with human subjects

Level of Study: Graduate

Type: Study grant

Value: Three US $\$ 1,000$ awards

Frequency: Annual

Country of Study: Any country

Application Procedure: The competition is open to both professional and student members of NCACES. The primary investigator must be an ACES/NCACES member at the time the application is submitted. Individuals may submit (or be part of a submission team) for only one proposal. ncaces.org/ awards/general/gsubmit

Closing Date: 29 June

Funding: Private

\section{North Dallas Bank \& Trust Company}

P.O. Box 801826, Dallas, TX 75380-1826, United States of America.

\section{Tel: $\quad$ (1) 8002757966}

Email: scholarships@thetrustcompany.com.au

Website: www.ndbt.com

The Trust Company is manager at a number high profile awards and scholarships made possible through Charitable bequests/trusts. These include the Miles Franklin Literary Award, Kathleen Mitchell Award (literary), Portia Geach Memorial Award (for female artists), the Sir Robert William Askin Operatic Travelling Scholarship (for male singers), the Lady Mollie Isabelle Askin Ballet Travelling Scholarship, and the Marten Bequest Travelling Scholarship.

\section{James W. Tyra Memorial Scholarship}

Purpose: In 1994, the executive management established the James W. Tyra Scholarship, in honor of the bank's very first Community Reinvestment Act ("CRA") Officer. Mr. Tyra was committed to advancing the hopes and dreams of the local public, and tirelessly gave of himself for the benefit of the youth in the community

Eligibility: 1. Must be a high school senior at time of application. 2. Must be a United States citizen or permanent resident. 3. Must be attending a public high school inside the North Dallas Bank \& Trust Company trade area (a list of eligible schools is available on the North Dallas Bank \& Trust Company website). 4 . Must be in the top $25 \%$ of his/her graduating class. 5. Must have a grade point average of 3.0 or higher. 6. the student must submit transcripts prior to the completion of each year of class, as failure to do so will result in loss of the scholarship

Level of Study: Graduate

Type: Scholarship

Value: US $\$ 1,000$

Frequency: Annual

Country of Study: United States of America

Application Procedure: 1. Each student must complete the scholarship application available in the counselor's office of his/her high school. Each applicant must be recommended by his/her high school counselor or principal. 2. In addition to the completed application, each student must submit a current official transcript, two letters of recommendation (one from a high school teacher, counselor, or principal and one from a community member)

Closing Date: 1 April

Funding: Private

Additional Information: www.unigo.com/scholarships/all/ james-w-tyra-memorial-scholarship/1559

\section{For further information contact:}

12900 Preston Road, Suite 208, Dallas, TX 75230, United States of America.

Tel: (1) 9727167299

Email: scholarships@swe.org

\section{North West Cancer Research Fund}

22 Oxford Street, Liverpool, L7 7BL, United Kingdom.

Tel: (44) 1517092919

Email: nwcrf@btclick.com

Website: www.cancerresearchnorthwest.co.uk

Contact: Mr A W Renison, General Secretary

\section{North West Cancer Research Fund Research Project Grants}

Purpose: To support fundamental research into the cause of cancers and the mechanisms by which cancers arise and exert their effects

Eligibility: Open to candidates undertaking cancer research studies at one of the universities named below in the Northwest. Grants are only available for travel costs associated with currently funded 3-year cancer research projects. No grants are awarded for buildings or for the development of drugs Level of Study: Research 
Type: Project

Value: Approx. $£ 35,000$ per year

Length of Study: Usually 3 years

Frequency: Dependent on funds available

Study Establishment: The University of Liverpool, Lancaster University and the University of Wales, Bangor

Country of Study: North West United Kingdom, North and Mid-Wales

Application Procedure: The NWCRF Scientific Committee meets twice a year. All applications are subject to peer review No. of awards offered: 50

Closing Date: 1 October

Funding: Private, Individuals

Contributor: Voluntary donations

No. of awards given last year: 10

No. of applicants last year: 50

\section{For further information contact:}

NWCRF Scientific Committee, Department of Medicine, Duncan Building, Daulby Street, Liverpool, L7 8XW, United Kingdom.

Email: ricketts@liverpool.ac.uk

\section{NWCR \& Tenovus PhD Studentship Award}

Purpose: We invite applications from principal investigators, with a track record of successful $\mathrm{PhD}$ supervision, to submit proposals for this jointly funded research award. NWCR and Tenovus Cancer Care (Tenovus) seek to fund a health services $\mathrm{PhD}$ research award which will aim to impact cancer policy or practice through the targeted area of psycho-social oncology. Level of Study: Research

Value: Maximum funding budget of up to $£ 75,000$

Length of Study: 3 years

Closing Date: 22 June

Funding: Private, Individuals

\section{Northeast Florida Phi Beta Kappa Alumni Association}

\section{Northeast Florida Phi Beta Kappa Alumni Association Scholarship}

Purpose: The Fall Program provides a social and intellectual opportunity for members and their guests

Eligibility: Winners will be honored at the association's Spring Banquet. For further details, see the website.

Level of Study: Postgraduate
Type: Scholarship and Research award

Value: US\$1,000

Frequency: Annual

Country of Study: Any country

Application Procedure: Application information is available online at the Phi Beta Kappa Alumni Association of Northeast Florida website

Closing Date: 1 March

Funding: Private

\section{For further information contact:}

1606 New Hampshire Avenue NW, Washington, DC 20009, United States of America.

Email: mroberts@unf.edu

\section{Northeastern University}

Graduate School of Business Administration, 350 Dodge Hall, 360 Huntington, Boston, MA 02115, United States of America.

Tel: $\quad$ (1) 6173732714

Email: gsba@neu.edu

Contact: MBA Admissions Officer

\section{National Robotics Initiative 2.0: Ubiquitous Collaborative Robots (NRI-2.0)}

Purpose: The goal of the National Robotics Initiative (NRI) is to support fundamental research that will accelerate the development and use of robots in the United States that work beside or cooperatively with people

Eligibility: 1. An investigator may participate as PI, co-PI, or Senior Personnel in no more than two proposals submitted in response to this solicitation each year. 2 . In the event that an individual exceeds this limit, proposals received within the limit will be accepted based on earliest date and time of proposal submission (i.e., the first two proposals received will be accepted and the remainder will be returned without review). No exceptions will be made. 3. The above limit applies only to proposals to the NRI-2.0 solicitation, not to the totality of proposals submitted to NSF

Level of Study: Graduate

Type: Grant

Frequency: Annual

Country of Study: Any country

Closing Date: 1 November

Funding: Private 
Additional Information: www.nsf.gov/funding/pgm summ.jsp?pims_id=503641

For further information contact:

Email: k.drew@neu.edu

\section{Northumbria University}

2 Ellison Pl, Newcastle upon Tyne NE1 8ST, United Kingdom.

Contact: Northumbria University

Northumbria University, officially the University of Northumbria at Newcastle, is a university located in Newcastle upon Tyne in the North East of United Kingdom. A former polytechnic, it was established as one of the new universities in 1992.

\section{Dean's Award Scholarship}

Purpose: Scholarships are available for pursuing full-time or part-time LPC or LLM LPC programme

Eligibility: For eligibility details, please visit website

Value: $£ 1,000$ with $90 \%$ off tuition fees

Country of Study: Any country

Application Procedure: Applications must be must be sent via email

Closing Date: 31 July

Contributor: Northumbria University

Additional Information: For more details, please visit website www.northumbria.ac.uk/study-at-northumbria/feesfunding/pg-fees-funding/2018-deans-award-lpc/ www.north umbria.ac.uk/study-at-northumbria/fees-funding/pg-feesfunding/2018-deans-award-bptc/

For further information contact:

Email: gradadms@mtu.edu

\section{Norway - the Official Site in the United States}

2720 34th Street NW, Washington, DC 20008, United States of America.

Tel: $\quad$ (1) 2023336000

Email: cg.newyork@mfa.no
Website: www.norway.org

Contact: Grants and Scholarships Department

\section{Al Fog Bergljot Kolflats Stipendfond}

Purpose: To provide a stipend for those who want to take a trip to the United States to get practical experience within their fields of interest

Eligibility: Open to Norwegian citizens only, especially for a Norwegian engineer or architect. The applicant must have worked for at least 3 years after graduation, and he/she must present a detailed plan for the trip when they apply. Also, a budget for the trip must be included as well as references

Level of Study: Postgraduate

Value: Up to NOK 30,000

Closing Date: 15 March

\section{For further information contact:}

The Norway-America Association, Rådhusgaten 23B, N-0158 Oslo, Norway.

Tel: $\quad$ (47) 23357160

Fax: (47) 23357175

Email: info@noram.no

\section{American-Scandinavian Foundation Scholarships (ASF)}

Purpose: To encourage Scandinavians to undertake advanced study and research programmes in the United States

Eligibility: Applicants must be citizens of Denmark, Finland, Iceland, Norway or Sweden and have completed their undergraduate degree. They should be fluent in English. Citizens of Finland, Iceland and Norway must apply through the sistersocieties in their home country

Level of Study: Postgraduate

Type: Fellowship

Value: The American-Scandinavian Foundation (ASF) offers over US\$500,000

Length of Study: 1 year

Frequency: Annual

Country of Study: United States of America Application Procedure: Applicants must complete an application on ASF application forms. More information available on our website - www.amscan.org/fellowships-and-grants/ fellowships-and-grants-for-advanced-study-or-research-in-theusa/

Funding: Foundation

Additional Information: www.amscan.org/fellowships-andgrants/fellowshipsgrants-to-study-in-scandinavia/ 


\section{For further information contact:}

58 Park Ave, New York, NY 10016, United States of America.

Tel: $\quad$ (1) 2128799779

Fax: (1) 2122493444

Email: grants@amscan.org

\section{John Dana Archbold Fellowship Program}

Purpose: To support educational exchange between the United States and Norway

Eligibility: Open to citizens of the United States citizens aged $20-35$, in good health and of good character. Qualified applicants must show evidence of a high level of competence in their chosen field, indicate a seriousness of purpose, and have a record of social adaptability. There is ordinarily no language requirement

Level of Study: Postdoctorate, Postgraduate, Professional development, Research

Type: Fellowship

Value: Up to US $\$ 5,000$. Individual grants vary, depending on the projected costs. Note that there will be no tuition at the University of Oslo. The maintenance stipend is sufficient to meet expenses for a single person. The travel allowance covers round trip airfare to Oslo

Length of Study: 1 year

Frequency: Annual

Study Establishment: The University of Oslo

Application Procedure: Applicants must write to the Nansen Fund, Inc. for an application form

Closing Date: 1 February

Funding: Private

Additional Information: The University of Oslo International Summer School offers orientation and Norwegian languages courses 6 weeks before the start of the regular academic year. For Americans, tuition is paid. Attendance is required. Americans visit Norway in even-numbered years and Norwegians visit the United States in odd-numbered years. For further information please contact the Nansen Fund, Inc grad.uchicago.edu/fellowship/john-dana-archboldfellowship-in-norway/

\section{For further information contact:}

Tel: $\quad$ (1) 7136808255

Email: nacc@net1.net

\section{Memorial Fund of 8 May}

Purpose: To promote cultural exchange between foreign countries and Norwegian residential experiential colleges by providing scholarships for residence, and to help prepare young people for everyday life in the community

Eligibility: Open to candidates aged $18-22$ years who do not have a permanent residence in Norway, and do not hold a Norwegian passport. Candidates must be planning to return to their home country after a year in Norway. Candidates must be aware of the kind of education the Memorial Fund bursaries cover, that being a year in a Norwegian residential colleges, not admission to education on a higher level, such as a university, or specialized training

Type: Scholarship

Value: The scholarship will cover board and lodging. In addition it is possible to apply for extra funds. Applicants from some countries may apply for required books and excursions arranged by the school. Also, extra support may be provided for short study trips and short courses before or after the school year. A fixed amount towards spending money may also be given. Normally the students must pay their own travelling expenses. The colleges do not charge tuition fees

Length of Study: 1 year

Frequency: Annual

Study Establishment: Norwegian residential experiential colleges

Country of Study: Norway

Application Procedure: Applicants must request more information and application forms from the Memorial Fund of 8 May or to the nearest Norwegian Embassy. Applicants who require a scholarship to attend a Norwegian college should not apply to a them directly. In this case, the Board will place successful applicants at a college school based on their hobbies and interest. Residence permits must be applied for by each individual student when a scholarship has been granted

No. of awards offered: 700

Closing Date: 1 November

Funding: Government

No. of awards given last year: 25

No. of applicants last year: 700

Additional Information: A residential experiential college is a 1-year independent residential school, primarily for young adults, offering many non-traditional subjects of study. Each college has its own profile, but as a group, the Norwegian colleges teach classes covering almost all areas, including history, arts, crafts, music, sports, philosophy, theatre, photography etc

\section{For further information contact:}

IKF, Grensen 9a, N-0159 Oslo, Norway.

Email: ikf@ikf.no 


\section{Norwegian Emigration Fund}

Purpose: To support for advanced or specialized study in Norway

Eligibility: Open to citizens and residents of the United States of America. The fund may also give grants to institutions in the United States of America whose activities are primarily centred on the subjects mentioned

Level of Study: Doctorate, Graduate, Professional development Type: Grant

Value: NOK 5,000-20,000

Frequency: Annual

Country of Study: Norway

Application Procedure: Applicants must complete an application form and return it clearly marked Emigration Fund to Nordmanns-Forbundet. Applications as well as enclosures will not be returned

Closing Date: 1 February

Funding: Government

\section{For further information contact:}

Email: norseman@online.no

\section{Norwegian Marshall Fund}

Purpose: To provide financial support for Americans to come to Norway to conduct postgraduate study or research in areas of mutual importance to Norway and the United States, thereby increasing knowledge, understanding and strengthening the ties of friendship between the two countries

Eligibility: Open to citizens of the United States, who have arranged with a Norwegian sponsor or research institution to pursue a research project or programme in Norway. Under special circumstances, the awards can be extended to Norwegians for study or research in the United States

Level of Study: Graduate, Postgraduate

Type: Research grant

Value: US $\$ 1,500-4,500$ or NOK $10,000-30,000$

Length of Study: Varies

Frequency: Annual

Study Establishment: Norwegian universities

Country of Study: Norway

Application Procedure: Applicants must contact the NorwayAmerica Association to receive an application. Application forms must be typewritten either in English or Norwegian and submitted in duplicate, including all supplementary materials. Each application must also be accompanied by a letter of support from the project sponsor or affiliated research institution in Norway. There is an application fee of NOK 350

Closing Date: 1 April

Funding: Private

\section{For further information contact:}

Tel: $\quad$ (47) 23357160

Fax: (47) 23357175

Email: info@noram.no

\section{The Norway-America Association Awards}

Eligibility: Open to Norwegian who wish to study in the United States on the graduate level, must have completed their Bachelor's Degree before applying for these scholarships. The applicants must also be members of the NorwayAmerica Association, and the membership fee is 200 NOK per year

Level of Study: Graduate, Research

Type: Award

Value: US $\$ 2,000-20,000$

Application Procedure: Check website for further details Closing Date: 22 September

Additional Information: Norwegians who reside in Norway and plan to return to Norway after graduation are given preference in the selection process, and they cannot have studied for four or more years in the United States. Please contact the American-Scandinavian Foundation or the Norway-America Association directly in order to find the appropriate scholarship

\section{For further information contact:}

Tel: $\quad$ (47) 23357160

Fax: (47) 23357175

Email: info@noram.no

\section{The Norway-America Association Graduate \& Research Stipend}

Purpose: To give the student substantial financial support for 1 year of studies in the United States

Eligibility: Open to Norwegians and members of the Norway-America Association, and he/she must pay 250 NOK in administrative fees and are currently living in Norway, and intend to return to Norway after their graduation Level of Study: Graduate, Research

Value: US\$2,000-25,000

Application Procedure: Check website for further details Closing Date: 22 September

\section{For further information contact:}

Tel: $\quad$ (47) 23357160

Fax: (47) 23357175

Email: info@noram.no 


\section{The Professional Development Award}

Purpose: To help established professionals with a higher education who want to study within their own field of interest Eligibility: Open to Norwegian professionals who worked for at least 3 years after finishing his or her education as well as planning on doing special research or further study in their fields Level of Study: Postgraduate

Type: Award

Value: The award amount can vary but there is a recommended minimum of US $\$ 250$ and maximum of US $\$ 1,000$ with only one award per student within a given academic year

Frequency: Annual

Application Procedure: Check website for further details Additional Information: Candidates must be invited to apply for this award. There is also an administrative fee of 250 NOK, which must be deposited in bank account with number 7878.05.23025. Please contact the AmericanScandinavian Foundation or the Norway-America Association directly in order to find the appropriate scholarship

\section{For further information contact:}

Tel: $\quad$ (47) 23357160

Fax: (47) 23357175

Email: info@noram.no

\section{The Torskeklubben Stipend}

Purpose: To promote Norwegian-American relations through helping Norwegians come to the United States to study

Eligibility: Open to Norwegians and must already be accepted at the Graduate School at the University of Minnesota before applying for the award

Level of Study: Graduate

Value: A stipend of US\$15,000 for the academic year. For recipients without another source of tuition support, such as an assistantship, the Graduate School Fellowship Office will provide a Tuition Scholarship for full-time study for the academic year

Frequency: Annual

Application Procedure: Application forms are available upon request from the Norway-America Association and the Graduate School at the University of Minnesota or it can be downloaded from the website

Closing Date: 1 March

\section{For further information contact:}

Tel: (47) 23357160

Fax: (47) 23357175

Email: info@noram.no

\section{Novo Nordisk A/S}

Novo Alle, Bagsvaerd, DK -2880, Denmark.

Contact: Director

\section{National Fellowship and Scholarship for Higher Education of ST Students}

Purpose: National Fellowship and Scholarship for Higher Education of ST Students is offered by Ministry of Tribal Affairs. This is a central sector scheme for the ST students who are selected for pursuing MPhil and PhD. The application form is available online and students can apply via the link given on this page. The scholarship has emerged as two different schemes i.e. Rajiv Gandhi National Fellowship for ST students and top class education for ST students. The fellowship covers under Rajiv Gandhi National Fellowship programme and scholarship is covered by top-class education Eligibility: 1. Candidates must belong to ST category. 2. Candidates should get registered for the full-time Mphil and $\mathrm{PhD}$ course. 3. scholarship, the students must have taken admission in their notified institution. 4. Family income should not exceed more than $6 \mathrm{Lac} \mathrm{P} / \mathrm{A}$

Level of Study: Postdoctorate

Type: Scholarship

Value: ₹25,000

Frequency: Annual

Country of Study: Any country

Closing Date: 31 October

Funding: Foundation

Additional Information: vikaspedia.in/education/policiesand-schemes/scholarships/p-g-and-above-scholarships/nationalfellowship-and-scholarship-for-higher-education-of-st-students

\section{For further information contact:}

Email: info@vidhyaa.in

\section{Novo Nordisk Foundation}

Tel: (45) 35276674

Email:_KEKV@novo.dk

Contact: Kirsten Klüver, Grant Administrator

The Novo Nordisk United Kingdom Research Foundation is a charity to support research into diabetes by members of the medical and nursing professions Research fellowships. 


\section{Postdoc Fellowship for Research Abroad}

Purpose: The Novo Nordisk Foundation invites young, ambitious researchers in Denmark to apply for a post-doctoral fellowship to conduct research within bioscience or basic biomedicine outside of Denmark

Eligibility: The applicant must be employed by a research institution in Denmark for the entire fellowship period and this institution must administrate the project grant

Type: Fellowship

Value: The Novo Nordisk Foundation awards DKK 1 million per year, that is, for a total of up to DKK 4 million/fellowship Length of Study: 4

Frequency: Annual

Country of Study: Denmark

Application Procedure: The application must be completed and submitted using the foundation's electronic application system

Closing Date: 1 February

Contributor: Novo Nordisk Foundation

Additional Information: For more information refer: novonordiskfonden.dk/sites/default/files/information_and guidelines_for_applicants_postdoc_fellowship_for_researc.pdf novonordiskfonden.dk/en/grants/postdoc-fellowship-for-rese arch-abroad-bioscience-and-basic-biomedicine/
For further information contact:

Email: info@novonordiskfonden.dk

\section{Nuffic}

Kortenaerkade 11, 2518 AX Den Haag, PO Box 29777, NL-2502 LT The Hague, Netherlands.

Tel: (31) 704260260

Email:_nuffic@nuffic.nl

Website: www.nuffic.net

\section{Netherlands Organization for International Cooperation in Higher Education-Natural Family Planning Fellowships for PhD Studies}

Eligibility: Candidate must be a national of one of 57 developing countries

Level of Study: Doctorate

Country of Study: Any country

Additional Information: www.european-funding-guide.eu/ other-financial-assistance/14452-nfp-fellowships-phd-studies 